\title{
Öğretim Elemanlarının İstenmeyen Davranışları İle Öğrenci Yabancılaşması Arasındaki İlişki*
}

\section{The Relationshıp Between Instructors' Misbehaviours And Undergraduate Students' Alienation}

\begin{abstract}
Abdulvehap BOZ
• Geliş Tarihi: 25.02.2019 • Kabul Tarihi: 12.09.2019 • Çevrimiçi Yayın Tarihi: 12.09.2019

$\ddot{O} z$

$\mathrm{Bu}$ çalışmanın amacı öğretim elemanları tarafindan sergilenen istenmeyen davranışlar ile üniversite öğrencilerinin yabancılaşma düzeyleri arasındaki ilişkiyi incelemektir. Çalışma nicel araştırma yöntemlerinden ilişkisel tarama modelinde tasarlanmıştır. Araştırmanın örneklemini 2017-2018 akademik y1lında Siirt Üniversitesinin faklı fakültlerinde öğrenim gören 347 öğrenciden oluşmaktadır. Araştırma kapsamında kullanılan verilerin toplanmasında Demografik Bilgi Formu, Öğretim Elemanları istenmeyen Davranışlar Ölçeği ve Öğrenci Yabancılaşma Ölçeği kullanılmıştır. Elde edilen veriler analizinde SPSS22 Packet Programı kullanılmıștır. Araştırma sonucunda öğretim elemanlarının orta düzeyde istenmeyen davranışlar sergiledikler ve üniversite öğrencilerinin orta düzeyde yabancılaşma yaşadıkları görülmüştür. Araştırmada elde edilen bir diğer bulguya göre öğretim elemanlarının istenmeyen davranışları ile üniversite öğrencilerinin yabancılaşma düzeyleri arasında pozitif yönde anlamlı bir ilişkiye rastlanmıştır Araştırmanın en önemli sonucu ise öğretim elemanı kaynaklı istenmeyen davranışların yabancılaşmaya aracılık ettiği olgusudur. Bulgular literatür çerçevesinde tartışılrmış ve ileriye dönük bazı önerilerde bulunulmuştur.
\end{abstract}

Anahtar Kelimeler: Öğretim elemanı, istenmeyen davranış, üniversite öğrencisi, okula yabancılaşma

Atıf:

Boz, A. (2020). Öğretim elemanlarının istenmeyen davranışları ile öğrenci yabancılaşması arasındaki ilişki. Pamukkale Üniversitesi Eğitim Fakültesi Dergisi, 49, 20-45. doi:10.9779/pauefd.532232.

Bu çalışma 1-4 Kasım 2018 tarihinde Antalya'da düzenlenen 9. Uluslararası Eğitim Yönetimi Forumunda bildiri olarak sunulmuştur.

${ }^{1}$ Dr. Öğretim Üyesi. Siirt Üniversitesi/ Eğitim Fakültesi Siirt

E-posta: sagacious56@yahoo.com (orcid.org/0000-0001-9843-0372) 


\begin{abstract}
The purpose of this study is to explore relationship between misbehaviours of instructors and undergraduate students' alienation. A rational model, quantitative research method, was used in present study. The participant of this study were randomly chosen from 347 undergraduate students enrolling in different faculty of Siirt University during summer semester of 2017-2018 academic year. The collected data for the investigation were gathered thought two different questionnaires included a demographic section. The findings of the study were analysed with SPSS-22 Packet Program. Findings of study revealed that instructor perform misbehaviours moderately, meanwhile perception of undergraduate students to alienation was measured as moderate. Furthermore, results showed that instructor misbehaviours have a positive and significant correlation with student alienation. Finally, the most significant contribution of this study is that instructor misbehaviours play a mediating role on student alienation.
\end{abstract}

Keywords: instructor, misbehaviour, undergraduate student, school alienation

\title{
Cited:
}

Boz, A. (2020). The relationship between instructors' misbehaviours and undergraduate students' alienation. Pamukkale Üniversitesi Eğitim Fakültesi Dergisi, 49, 20-45.doi: 10.9779/pauefd.532232. 


\section{Giriş}

Öğrenme ve öğretme süreci karmaşık, zor, büyük özveri, sabır ve duygudaşlık gerektiren meşakkatli bir süreçtir. Ancak bu zorluklara rağmen öğretmenlik mesleğinin kazanımlar bakımından cazip bir meslek olduğu söylenemez (Kearney, Plax, Hays ve Ivey. 1991). Stres düzeyi yüksek (Clipa ve Boghean, 2015) buna karşın ekonomik getirisi (Sönmez, 1989) ve statüsü (Ünsal, 2018) düşük olan bu meslek grubunun üyeleri arasında sıklıkla istenmeyen davranışların görülmesi sürpriz bir sonuç olarak değerlendirilmemektedir. Öğretmen/öğretim elemanı istenmeyen davranışlar öğrencileri özelde sınıf içi etkinliklerden genelde ise eğitim sürecinden uzaklaştıran (Finn, 1989) önemli bir sorundur. İstenmeyen davranışlar ile karşılaşan öğrencilerin öğrenme sürecinden uzaklaşmaları, okul ile olan bağlarının kopması ve okula yabancılaşmaları güçlü bir olasılık olarak görülmektedir.

Öğretmen/öğretim elemanları açık ve gizli yetişek aracıllı̆̆ıla öğrencilerin toplumsal, kişisel ve mesleki gelişimlerine önemli katkılar sunmaktadır. Kültürel mirasın aktarımı, sosyalleşme, ekonomik ve teknolojik yetkinlik kazandırma, meslek ve statü edinme gibi kazanımlar öğretmen/öğretim elemanlarının çabaları sonucu elde edilen kazanımlardır. Ancak ne yazık ki, bütün öğretmen/öğretim elemanları öğrenme sürecine her zaman olumlu katkı sunamamaktadır. Araştırmalar öğretim elemanlarının sıklıkla öğrencileri rahatsız eden, öğrenmelerini engelleyen istenmeyen davranışlar sergilediklerini ortaya koymaktadır (Bolkan ve Goodboy, 2016). Görüldüğü gibi öğretmen/öğretim elemanlarının kişisel ve mesleki gelişim düzeylerinin yanı sıra tutum ve davranışları da eğitim kurumlarının başarısı için yaşamsal bir önem arz etmektedir. Olumlu tutum ve davranışlar öğrenme çıktılarına pozitif anlamda katk1 sunmakta buna karşın olumsuz tutum ve davranışlar başarı açsından bariyere dönüşmektedir.

Eğitim kurumları kaliteli ve etkili bir öğrenme çevresi oluşturma çabasına girişirken pek çok zorluk ve problem ile mücadele etmek durumundadır. Kaliteli eğitimin önündeki en önemli problem alanlarından biri olarak kabul edilen istenmeyen davranışlar eğitim kurumlarının karşı karşıya kadıkları zorlukların başında gelmektedir (Kearney vd, 1991; Bolkan ve Goodboy; 2016; Goodboy ve Bolkan; 2009; Meyers, 2002). Eğitim ve öğretim sürecinde meydana gelen hemen her istenmeyen davranış öğrenme sürecini olumsuz yönde etkilemektedir. Başka bir deyişle, ister öğrenci kaynaklı isterse öğretim elemanı kaynaklı olsun sınıf içinde meydana gelen her istenmeyen davranış hemen her kademedeki öğretmen/öğretim elemanın karşılaşabileceği en önemli yönetimsel sorunlardan biri olarak kabul edilmektedir. İstenmeyen davranışlar öğrenci bağllık düzeyini düşürmekte (Kelsey, Kearney, Plax, Allen, Ritter, 2004) ve eğitim çıktılarını (Goodboy ve Meyers, 2008) olumsuz etkilemektedir. Bu nedenle kaliteli bir öğretimin önündeki en büyük engellerden biri olarak kabul edilen istenmeyen davranışları ortadan kaldırmak her eğitim kurumunun en öncelikli görevi ve amacı olmalıdır.

Geleneksel görüşe göre başarı için yetenek ve motivasyon yeterli faktörlerdir (Kurs, Woolfolk Hoy ve Hoy, 2007). Bu noktadan hareketle okula yabancılaşmanın başarıya ulaşmanın önünde bir engel olduğunu ileri sürmek mümkündür nitekim araştırmalar yabancılaşmanın motivasyonu düşürdügünü (Goodboy ve Bolkan, 2009; Hoy, 1972; Kelsey vd, 2004) göstermektedir. Üniversite geçliği için büyüleci ve cazip bir deneyim evresi olması gereken üniversite yılları yaşanan zorluk ve problemlerden dolayı öğrenciler açısından yaşamlarının en zor dönemlerine dönüşebilmektedir (Kumar, 2018). Büyük umutlarla üniversite yaşamlarına başlayan gençler beklentilelerini karşılamaktan uzak bir çevre ile karşılaştıkarında 
bağlılık ve motivasyonlarını kaybetmekte ve okulu Mau'nun (1992) deyişiyle hayak kırıklığına uğrdaıkları bir mekan olarak görmektedirler. Bu durum geleceğin inşasında dinamik ve etkin bir rol oynayan üniversite gençliği, aileler ve toplum açısından büyük kırılmalarla sonuçlanmaktadır.

Görüldüğü gibi istenmeyen davranışlar eğitim açısından çeşitli olumsuzluklarla sonuçlanmaktadır. İstenmeyen davranışların sebep olduğu negatif olgulardan birinin de yabancilaşma olduğu varsayılmaktadır. Toplumsal ve tarihsel bir olgu olan seri üretim kitlesel tüketim ile birlikte yeni bir yaşam ve üretim biçimi (Günay, 2002) doğurdu. Sanayileşemenin ürünü olan makineleşmeyle birlikte insan değersiz bir nesneye dönüşmüş ve kendi yaratısına yabancılaşmıştır (Marx, 1884). İnsana biçilen değer salt insanın yaratısı olan üretim ile sınırlandırıldı. Bu bağlamda toplumsal değişim ve dönüşüm sonucu ortaya çıkan seri üretim ilişkilerini bir yönüyle insan devşirme sanatı olarak değerlendirmek mümkündür.

Bilim, teknoloji, kapitalist üretim ilişkileri, şehirleşme yabancılaşmayı doğuran koşulların başında yer almaktadır. İnsan doğası gereği çevresinde meydana gelen kültürel, sosyal, ekonomik ve tekonolojik değişim ve dönüşümelere bir şekilde tepki vermektedir, bu tepki bazen uyum bazen de bir başkaldırı şeklinde gelişebilir. Özellikle değişim ve dönüşümleri değerleriyle uyumlaştıramayan insan güçlü kopuşlar yaşamaktadır. Bu kopuşlar zamanla öfkeye ve nihayetinde yabancılaşmaya evrilir. Kapitalist sistem ve küreselleşme insanın köleleşme sürecini hızlandırmış ve kapitalist üretim ilişkilerinin tutsağına dönüşen insan zaman içerisinde topluma ve kendine yabancılaşmıştır. Kapitalist üretim tarzı insanı salt bioyolojik bir varlık olarak değerlendirip, emeğini sömürmeyi doğal bir süreç olarak görmeye başladı (Erdemir, 1982).

Kapitalist üretim süreci çok sayıda olumsuz örgütsel tutum ve davranışa aracılık etti. Kapitalist üretim ilişkilerinin kaynaklık ettiği en önemli olumsuz davranışlarından biri de yabancılaşmadır. Sanayi devrimiyle birlikte ivme kazanan kapitalist üretim ilişkileri insanın kendini gerçekleştirme amacından uzaklaştırmış ve mutlu olma arayışına ket vurmuştur. Tabiiatıyla bu durum insanın kendine yabancılaşmasıyla sonuçlanmıştır. Kapilalist üretim ilişkilerindeki bu değişimler insan kendi özgür iradesiyle karar alamaz duruma hale getirmiş ve tutsak bir bireye dönüştürmüştür. Nihayetinde kendi özüne yabancılaşan insan mutululuğunu, ikinci plana atarak bütün potansiyelini ve enerjisini başkalarının mutluluğu için harcamaya başlamıştır (Yılmaz ve Sarpkaya, 2009). Martinez'in ifadesiyle (2015) yabancılaşma bireyin yaşadığı topluma, toplumsal ve teknolojik değişim ve yeniliklere uyum sağlamasını engelleyen önemli bir faktördür.

Yabancılaşma yaş, cinsiyet, meslek ve kültür farklılıklarını gözardı ederek hemen tüm bireylerde ortaya çıkan psikolojk bir olgudur. Üniversite öğrencileri arasındaki yabancılaşma olgusu pek çok ülke açısından ciddi bir problem olarak görülmektedir. Yabancılşamanın sorun olarak algılanmasının temel sebebi kavramın olumsuz dışssalıklarında yatmaktadır. Yabancılaşma bireyin okula ve eğitime karşı olumsuz tutumlar geliştirmesine (Seeman, 1959), öğrenme etkinliklerinden uzaklaşmasına neden olan (Finn, 1989; Murdock, 1999) sosyopsikolojik bir (Şimşek ve Akdemir, 20059 durumdur. Alanyazında öğrenci yabancılaşmasının sıklıkla okuldaki diğer öğrencilere, öğretmenlere ve yönetime karşı bağlantısızlıkla ilişkilendirildiği görülmektedir (Warner, Weist ve Krulak, 1999). Bu bağlamda düşünüldüğünde okula yabancılaşmanın öğrenci öğrenme sürecinden alıkoyan ciddi bir problem olduğu 
görülmeketedir. Benzer şekilde Mann (2001) yabancılaşma kavramını bir gruptan veya katılması gereken bir etkinlikten izole olma durumu şeklinde açıklamaktadır. Bir başka tanımda yabancılaşmanın insanın bastırılması ve kapasitesinin sınırlandırılması olarak değerlendirildiği görülmektedir (Yüksel, 2014).

\section{İstenmeyen Davranışlar}

İstenmeyen öğretmen/öğretim elemanı davranışları fiziksel ve cinsel saldırı, bağırma, hakaret etme, ters bakma, görmezden gelme (Kearney vd, 1991), sınıfa geç gelme, iğneleyici söz söyleme (Sidelinger, Bolen, Frisby ve McMullen, 2011) gibi geniş bir yelpazede yer alan olumsuz davranışları kapsamaktadır.

İstenmeyen davranışlara yönelik sistematik araştırma sayısında önemli bir artış gözlenmektedir. Kearney ve arkadaşları (1991) öğretim elemanı kaynaklı istenmeyen davranışları öğrencileri öğrenme sürecinden alıkoyan ve öğrenmeyi engelleyen davranış olarak nitelendirmektedir (Kearney, 1991). Aynı çalışmada Kearney ve arkadaşları öğrencilerden aldıkları verilere dayanarak öğretim elemanlarının istenmeyen 28 davranışını belirlemiş ve bunları savunmacılık, tembellik ve yetersizlik olmak üzere üç kategoride sınıflandırmıştır. Kearney ve arkadaşlarına (1991) göre öğretmenlerin istenmeyen davranışlarına aracılık eden temel faktörler yukarıda belirtilen üç nedenden kaynaklanmaktadır. Zhang'ın (2007) yaptığı araştırma sonuçlarına göre öğretmenlere atfedilen bu üç özellikten en yaygın ve rahatsız edici olanının yetersizlik olduğunu görülmüştür. Goodboy ve Bolkan (2009) istenmeyen öğretmen davranışlarının öğrenci iletişimi ve akademik başarılarına etkisini inceledikleri çalışmalarında öğretmen kaynaklı istenmeyen davranışlar ile direnç, motivasyon, katılım ve zihinsel öğrenme süreci arasında doğrudan ve dolaylı ilişkiler tespit etmişlerdir.

İstenmeyen davranışlar ile sınıf içi pozitif davranışlar arasındaki ilişkiler incelendiğinde, istenmeyen davranışlar ile sınıf içi olumlu davranışlar arasında negatif bir ilişkinin olduğu görülmektedir. Örneğin, Fernandez-Balboa'unun (1991) ifade ettiği gibi istenmeyen davranışlar öğrenme için ayrılan ve zaten kısıtlı olan zamanı daha da azaltmaktadır. Balboa ile paralel görüşler ileri süren Wragg ve Dooley (1996) öğretmenlerin eğitim için ayrılan zamanlarının büyük bir kısmını disiplini sağlamak için kullandıklarını belirtmektedir. İstenmeyen davranışlar öğretmenler ve öğretim elemanları için o kadar rahatsız edici ki, bir Profesör (Sorcinelli, 1994) istenmeyen davranışlar sergileyen öğrencileri "Sinıf teröristleri" olarak nitelendirmektedir. Bu çarpıcı metafor istenmeyen davranışların öğretmenleri/öğretim elemanlarını sürüklediği psikolojik durumu ifade etmesi bakımından son derece anlamlıdır.

Öğretim elemanı kaynaklı istenmeyen davranışlar öğrencilerde olumsuz tutum ve davranışların gelişmesi açısından elverişli bir ortam yaratır. Nitekim çok sayıda araştırmacı (Demirtaş, 2016; Goodboy ve Bolkan, 2009; Kelsey vd, 2004) öğretim elemanı kaynaklı istenmeyen davranışların öğrencileri olumsuz düşüncelere savurduklarını ve düşük motivasyona neden olduklarını ileri sürmektedir. Bu bulgular istenmeyen davranışların etkili öğrenme sürecini zehirlediğini ortaya koymaktadır. İstenmeyen davranışlar kaliteli öğrenme açısından kritik role sahip olan iletişimi de olumsuz yönde etkilemektedir (Ratcliff, Jones, Costner, Savage-David ve Hunt, 2011). Ayrıca araştırmalar bireyin motivasyon ve bağlılı̆̆ını olumsuz yönden etkileyen stresin en önemli öncülünün fiziksel veya sözlü olarak ortaya çıan sınıf içi istenmeyen davranışlar olduğunu göstermektedir (Charlton ve David, 2013). 
Eğitim kurumlarında meydana gelen istenmeyen davranışlara yönelik yapılan çalışmaların öğrenci kaynaklı istenmeyen davranışlara odaklandığı görülmektedir. Başka bir deyimle öğrenci kaynaklı istenmeyen davranışların öğretmen perspektifiyle geniş bir şekilde araştırıldığı buna karşın öğretmen/öğretim elemanı istenmeyen davranışların araştırmacıların ilgisini çekmediği ve bu alanın ihmal edildiği düşünülmektedir. Oysaki öğretmen/öğretim elemanı tarafından sergilenen istenmeyen davranışların en az öğrenci kaynaklı istenmeyen davranışlar kadar eğitim-öğretim etkinliklerini olumsuz etkilediği ve öğrenmeyi engellediği değerlendirilmektedir (Bolkan ve Goodboy, 2016; Goodboy, Myers ve Bolkan, 2010; Goodboy ve Bolkan; 2009; Kelsey vd, 2004; Meyers, 2002).

İstenmeyen davranışlar eğitimin her kademesinde görülmektedir. Araştırmalar bu savımızı destekler niteliktedir. Nitekim alan yazında konu ile ilgili yapılan çalışmalar eğitimöğretim faaliyetlerini sınırlandıran istenmeyen davranışlar sorununun sadece okul öncesi, ilköğretim ve orta öğretim ile sınırlı olmadığını aynı zamanda üniversite aşamasında da sıklıkla karşılaşılan bir olgu olduğunu ortaya koymaktadır. (Ataş ve Yücel, 2015; Ayık, Uzun; Polat, Dilekmen, Yasul, 2015; Çağlar, 2012; Bolkan ve Goodboy, 2016; Goodboy ve Bolkan, 2009; Şimşek ve Akdemir, 2015; Vallade ve Myers, 2014). Daha önce ifade edildiği gibi istenmeyen davranışlar sadece öğrenciler ile sınırlı olmadığı aynı zamanda öğretmen ve öğretim elemanlarının da sıklıkla istenmeyen davranışlar sergiledikleri görülmektedir (Kelsey vd, 2004; Vallade ve Myers, 2014; Özer ve Bozanoğlu, 2016). Vallade ve Myers'e (2014) göre öğretim elemanlarının istenmeyen davranışları hem öğretim elemanı hem de öğrenciler açısından olumsuz sonuçlar doğuracağı yadsınamaz bir gerçekliktir.

Alan yazın incelendiğinde öğretim elemanı kaynaklı istenmeyen davranışların öğrencilerin öğrenme motivasyonlarını düşürdüğünü, ilgi ve bağlılık düzeylerini olumsuz yönde etkilediğini göstermektedir (Claus, Booth-Butterfield ve Chory, 2012; Goodboy ve Bolkan, 2009; Gorham ve Milette, 1997; Kelsey, 2004; Meyers, 2002). Demirtaş (2016) tarafindan yapılan araştırmada istenmeyen davranışlar ile öğrencilerin derse katılım düzeyleri arasında negatif bir ilişki tespit edilmiştir. Buna karşın öğrenciler ile yakın ilişki kuran öğretmen/öğretim elemanları öğrencilerin kendini ifade etme konusunda daha özgür hissetmelerine olanak sapladığ 1 için (Frisby vd, 2014) bilişsel, duygusal ve davranışlar boyutlarda daha yüksek düzeyde katılım (Anderman, Andrzejewski ve Allen, 2011) sağladıkları görülmektedir.

\section{Yabancılaşma}

Yabancılaşma kavramı sosyolojik, psikolojik, teolojik, felsefi ve tarihi persperktifle incelenmiş ve farklı bağlamlarda kullanılmıştır (Morinaj vd, 2017). Yabancılaşma terimi hem çağdaş literatürü hem de sosyolojik düşünce tarihini domine eden ve Marx, Weber ve Durkheim'in klasiklerinin çekirdeğini oluşturan bir kavramdır (Seeman, 1959). Sosyal bilimlerde iki yüzyıldan beri ilgi odağı olan yabancılaşma her ne kadar felsefi açıdan ilk kez Hegel tarafindan analiz edilmiş ve Hegelin yabancılaşma konusunda görüşlerine eleştirel açıdan yaklaşan Feuerbach ile popüleritisi artmışsa da kavramın Marx ile özdeşleştiği görülmektedir. Marx (1884) yabancılaşmyı ekonomik sistem üzerinden inclemiştir. Hegel, yabancılaşmayı bilişsel bir durum olarak tahlil etmekte ve yabancılaşmayı doğanın Mutlak Tinin kendine yabancılaşmış biçimi olarak nitelendirmektedir. Hegel yabancılaşma kavramını bireyin kendi kendini ortadan kaldırmas1 olarak değerlendirmektedir (Erdost, 2013). Marx (1844) kendisinden önce yabancılaşmayı felsefi açıdan inceleyen Hegel ve Feuerbach'a ciddi eleştriler getirmektedir. 
Marx Hegel'i nesnelleşme ile yabancılaşmayı özdeşletirdiği için eleştirirken, Feuerbach'1 yabancılaşmayı dini yabancılaşmaya karşılık olarak kullandığı için tenkit etmektedir.

Eleştirel-teorik felsefi bir kategori olarak geliştirilmiş (Özatalay, 2018) olan yabancılaşma kavramını Erdost (2013) Marx'ın yabancılaşma konusunda kaleme aldığ metinlerden oluşan derlemesinde insanın kendi emeği sonucu ortaya koyduğu ürünlere, doğaya, kendi özüne, insanlığa ve çevresine yabancılaştıran eylem olarak tanımlamaktadır. Marx'a (1844) göre yabancılaşma ancak kapitalist ekonomik sistemin bertaraf ve kominist ideolojinin yabancılaşmanın yerini almasıyla ortadan kaldırılabilir.

Psikanalizin kurucusu olan ve bu yaklaşımın doruğu olarak kabul edilen Freud (Kumari ve Kumar, 2017) yabancılaşmayı gerçeklikten kopuş olarak tarif etmektedir. Case (2008) tarafından yapılan tanımda yabancılaşma arzulanan ve umulan ilişkilerdeki bağlantısızlık olarak nitelendirilmektedir. Tolan'a (1981) göre yabancılaşma insani olmayan bir durumdur. Yabancılaşma insanın öz benliğini kaybetmesine ve psiko-sosyal açıdan parçalanmasına ve nihayet kendinden kopup, uzaklaşmasına yol açmaktadır. Hascher ve Hadjar (2018) ise yabancılaşmayı birey ile çevresiyle ilişkilerinde yaşadığı ilgisizlik, bağlantısızlık ve düşmanlık sonucu çevresine karş1 göstermiş olduğu tepki olarak nitelendirmektedir. Yabancılaşmayı tanımlayan diğer bir araştırmacı olan Mann (2001) kavramı bir gruptan veya katılması gereken bir etkinlikten izole olma durumu olarak açıklamaktadır. Eğitim bilimlerinde yabancılaşma tanımlanırken öğrencilerin okula ve eğitime karşı takındığı olumsuz tutumlara gönderme yapıldığı görülmektedir (Seeman, 1959).

Yabancılaşma kavramı üzerinde yapılan araştırmaların genellikle Seeman (1959) sınıflandırması temel alınarak yapıldığı görülmektedir. Seeman (1959) yabancılaşmayı güçsüzlük, anlamsızlık, kuralsızlık, sosyal uzaklaşma ve kendine yabancılaşma olmak üzere beş alt boyutta incelemektedir. Yabancılaşma bireyin sadece fiziksel olarak yaşamını sürdürdüğü çevresinden izole olmasıyla sınırlı olmayıp ayrıca bireyin zihinsel, duygusal ve davranışsal açıdan bulunduğu çevreden kopuşa da aracılık eden bir durumdur. Nitekim yabancılaşma ile örgütsel ve bireysel davranışlar arasındaki ilişkiyi inceleyen çok sayıda araştırmada yabancılaşma ile performans (Banai ve Reisel, 2003; Kartal, 2017), iş tatmini (Artar, Adıgüzel ve Erdil, 2017; Orpen, 1978) bağlılık (Tummers ve Dulk, 2013), motivasyon (Atnafu, 2002; Özdemir ve Rahimi, 2013;) gibi olumlu işgören tutum ve davranışları arasında negatif bir ilişkinin varlığına işaret ederken, yabancılaşma ile işgören stresi (Erkılıç, 2012), örgütsel sinizm (Yıldız ve Şaylıkay, 2014; Yıldız, Akgün, Yıldız, 2013), örgütsel tükenmişlik (Özler ve Dirican, 2014) gibi olumsuz işgören tutum ve davranışları arasında ise pozitif yönlü bir ilişki saptanmıştır.

\section{Okula Yabancılaşma}

Eğitim çevrelerinde yaşanan yabancılşamya ilişikin araştırma sayısı sınırlı olmakla birlikte son yıllarda konuya olan ilginin arttığı gözlenmektedir. Öğrenci yabancılaşmasının okul kademesine, okul türüne, öğrencilerin demografik özelliklerine ve çevreye özgü bir durum olmadığı ve hemen her eğitim kademesinde görülebilen, eğitim açısından ciddi riskler barındıran bir sorun olduğu görülmekteidir. Dean (1961) okula yabancılaşmayı "akademik yabancılaşma" olarak kavramlaşırmıştır. Kavramlaştırmayı Markist bir temele oturtan Dean, (Dean, 1961, Akt. McPhee ve McEntee, 2014) öğrenci yabancılaşmasını sosyal yabancılaşma, normsuzluk ve güçsüzlük olmak üzere üç alt boyutta incelemiştir. 
Okula yabancılaşma kavramına yönelik yapılan saptamalar dikkate alındığında kavramı bireyin öğrenim gördüğü okula, sınıfa, okuldaki akranlarına ve öğretmene yönelik beslediği olumsuz tutum ve davranışların sonucu olarak bireyin zihinsel, duygusal ve davranışsal olarak öğrenme sürecinden kopma diye nitelendirmek olasıdır. Nitekim bazı yazarlar öğrenci yabancılaşmasını öğrenme sürecinden uzaklaşma olarak tanımlanmaktadır (Brown, Higgins, Pierce, Finn, 1989; Hong ve Thoma 2003; Johnson, 2005). Benzer şekilde Hascher ve Hagenauer (2010) okul/öğrenci yabancılaşmasını bireyin eğitim sürecinden zihinsel ve duygusal uzaklığı olarak nitelendirmektedir. Okula yabancılaşma konusuna değinen bir başka yazar, Newmann (1981) ise öğrenci yabancılaşmasının sadece öğrencinin yaşam kalitesini olumsuz etkilemekle sınırlı olmadığını aynı zamanda şiddet, barbarlık ve düşük başarı gibi okul sorunlarına da yol açtığını belirtmektedir. Görüldüğü gibi okula yabancılaşma öğrenciyi eğitim sürecine karşı negatif tutum ve davranışlar sergilemeye yönelten hatta kuşaklar arası çatışmaya neden olabilecek (Tezcan, 1998) kadar önemli bir sorun olarak karşımıza çıkmaktadır.

Hascher ve Hadjar (2018) 1990 ile 2017 yılları arasında okul/öğrenci yabancılaşması üzerinde yapılan 132 araştırmayı incelemiş ve söz konusu araştırmaların yabancılaşma ile şiddet, okul terk, cezalandırma, okul büyüklügü ve okul iklimi gibi değişkenler ile olan ilişkilere odaklandığını ifade etmektedir. Aynı çalışmada, okula yabancılaşma ile ilgili araştırmaların okula yabancılaşma türleri, belirti ve göstergeleri ile bu alandaki ampirik çalışmaları kapsadığı belirlenmiştir (Hascher ve Hadjar, 2018). Üniversite öğrencileri ve yabancılaşma konusunda yapılan araştırmaların bir kısmı öğrencilerin kavrama ilişkin algılarını belirlemeye (Kelsey vd, 2004) çalışırken bir kısmı da bir okula yönelik tutum (Erimez ve Giriz,2013), ilişki boyutu (Şimşek ve Akdemir (2015), akademik öz-yeterlilik (Polat vd, 2015), sinizm (Ayık vd, 2015) ve bağl1lık (Mann, 2001) gibi farklı değişkenler ile ilişkilendirilmiştir.

Her ne kadar Prasad ve Prasad (1993) ampirik çalışma ve araştırmaların otuz yılı aşkın bir süredir yabancılaşmaya yol açan örgütsel koşulların belirlenmesinde başarısız olduğunu ileri sürseler de bu alanda yapılan bazı çalışmalar yabancılaşmaya neden olan koşul ve faktörlerin aydınlığa kavuşturulmasında önemli katkılar sunmuştur (Chiaburu, Thundiyil ve Wang. 2014). Örneğin, Chiaburu ve arkadaşları yabancılaşmanın açıklanmasında ve tanımlanmasında kullanılan bazı kavramlarını alana kazandırılmasında önemli katkılar sunmuştur. Aynı çalışmada destekleyici liderlik ve örgütsel destek gibi örgütsel koşulların yabancılaşmaya neden olan faktörlerin ortadan kaldırılmasında etkili oldukları ortaya konmuştur (Chiaburu, Thundiyil, ve Wang, 2014).

\section{Okul/Öğrenci Yabancılaşmasının Sebepleri}

Eğitim yaşamlarına önyargılarından uzak ve pozitif duygularla başlayan bireylerde çeşitli nedenlerden dolayı söz konusu kurumlara karşı zamanla negatif tutum ve davranışlar gelişmeye başlamaktadır (Hascher ve Hadjar, 2018). Belkide bunun temel sebebi eğitim kurumlarının özgürlükleri kısıtlayıcı özelliğidir. Tüm çabası özgürleşmek temeline dayanan insan, teknolojik değişim ve üretimin yeniden şekillenmesi sonucu kendi doğasına yabancılaşmıştır (Marx, 1884; Yılmaz ve Sarpkaya, 2009). Okul/öğrenci yabancılaşmasının dolaylı ve doğrudan yansımalarının çok ve çeşitli olması nedeniyle kavram araştırmacıların ilgi odağı haline gelmiştir. Özellikle eğitim açısından yol açtığ yıkıcı tahribat öğrenci yabancılaşmasına sebep olan öncüllerin belirlenmesinin gerekliliğini artırmış ve bu durum kavrama ilişkin çok sayıda araştırmanın yapılmasına öncülük etmiştir. Araştırma bulguları öğrenci yabancılaşmasına 
aracılık eden faktörlerin çeşitliğine işaret etmektedir. Okul/öğrenci yabancılaşmasının olumsuz yansımalarının akademik boyuttaki etkisinin oldukça yaygın olduğu değerlendirilmektedir. Nitekim kayda değer sayıda araştırmacı (Brown vd, 2003; Cadieux, 2002; Johnson, 2005; Goodboy ve Bolkan, 2009) öğrenci yabancılaşmasının okulu terk etme ve öğrenciler arasında çeteleşme ile sonuçlandığını, ayrıca okul-öğrenci ve öğrenci-öğretmen ilişkisinin bozulmasına aracılık ettiğini ileri sürmektedir. Hascher ve Hagenauer (2010) ise okula yönelik motivasyon eksikliğinin okula yabancılaşmanın nedeni olarak görmektedirler.

Eğitim kurumlarındaki yabancılaşmayı konu edinen bir çalışmada (Kumari ve Kumar, 2017) öğrencilerin akademik ve sosyal deneyimlerinin yabancılaşmanın gelişmesinde önemli etkileri olduğunu ortaya koymuştur. Çünkü okul çevresi öğrenciler için yıkıcı ve tahrip edici bir etkiye sahiptir. Goodwin (2000) yabancılaşma ve akademik başarısızlığa yol açan etkenleri altı başlık altında incelemiştir, yazar bunları;

- Zayif veya uygun olmayan müfredat

- Etkisiz öğretim

- Ayrımcı sınıf içi söylem

- Düşük benlik algisı

- Okul kültürünü oluşturmaya yönelik başarısız düzenlemeler, şeklinde sıralamıştır.

Günümüzün yaşam koşulları bir bakıma yabancılaşmayı kaçınılmaz bir sonuç olarak bireylere dayatmaktadır denebilir. Hayatlarının en aktif ve dinamik dönemlerini geçirmekte olan yükseköğrenim gençliğinin bu gerçeklikten soyutlanması başka bir deyişle söz konusu olgunun negatif sonuçlarından etkilenmeyeceğini varsaymak kaba bir iyimserlik olur. Nitekim yükseköğrenim kurumlarındaki yabancılaşma olgusunu altı farklı teorik perspektiften inceleyen Mann (2001) sosyokültürel bağlam, üstünlük söylemi, bilgi, güç ve öngörü, öğretme-öğrenme süreci, öğrenme sürecinden kopuş ve değerlendirme uygulamalarının yabancılaşmaya aracılık ettiğini ileri sürmektedir. Hascher ve Hagenauer (2010) Newmann' in (1981) derlemelerinden yola çıkarak öğrenciler arasında yabancılaşmanın önlenmesinde etkili, olan (1) Otonomidestekleyici öğrenme çevresi, (2) öğretim kalitesi, (3) öğretmen-öğrenci etkileşimi ve (4) öğrenci-öğrenci etkileşimi olmak üzere dört temel faktör belirlemişlerdir.

Cinsiyet ve sınıf içi iletişim gibi faktörlerin yabancılaşmanın düzeyini etkilediği değerlendirilmektedir. Nitekim Atnafu, (2012), yaptığı araştırmada kız öğrencilerin erkek ögrencilere göre daha yüksek düzeyde yabancılaşma yaşadıklarını tespit etmiştir. Konu ile ilgili yapılan bir başka çalışmada (Morinaj ve Hascher, 2017) erkek öğrencilerin yabancılaşma algılarının kız öğrencilere göre daha yüksek olduğu görülmüştür. Hascher ve Hagenauer (2010), tarafından "Okul Yabancılaşması" adlı çalışmasının bulguları, yabancılaşmanın erkek ve başarı düzeyi düşük öğrenciler arasında daha yaygın olduğunu ortaya koymaktadır. Aynı çalışmada eğitimin kalitesi, öğretmen-öğrenci etkileşimi ve öğrenci-öğrenci ilişkisinin öğrenci yabancılaşması üzerinde etkili olduğu ve söz konusu üç faktör arasında en etkili faktörün öğretmen-öğrenci ilişkisi olduğu görülmüştür. Konu ile ilgili yapılan başka bir çalışmada benzer sonuçlara ulaşılmıştır. Örneğin Rovai ve Wighting (2005) tarafından gerçekleştirilen çalışmanın bulguları sınıf içi iletişim ile öğrenci yabancılaşması arasında negatif yönlü bir ilişkiye işaret etmektedir. Bu bağlamda düşünüldüğünde sınıf içi iletişimsizlik veya zayıf iletişimin öğrencileri kendi içinde bir yalnızlığa itmesi ve bunun sonucunda öğrencilerin anti-sosyal davranışlar sergilemeleri olasidır. 
Doğrudan üniversite öğrencilerinin yaşadığı yabancılaşma konusuna değinen araştırmalarda üniversite müfredatının öğrenci açısından önemli derece yabancılaşmaya aracılık ettiğini göstermektedir. Örneğin, öğrenciler, müfredatta yer alan ve zihinlerini dolduran pek çok konunun gereksiz olduğunu ve ilerideki yaşamlarına hiçbir katkısının olmadığını düşünmektedir. Başka bir deyişle öğrenciler müfredatta yer alan konuların kazanımları ile gerçek yaşam arasında bir bağ kuramamakta ve bu kazanımlar günlük problemlerin çözümüne herhangi bir katk1 sunmamaktadır. Dolayısıyla müfredat içeriği öğrenciler için anlamsız bir durum kazanmaktadır denebilir. Bu durum Taylor'un (2001) ifadesiyle öğrencilerin üniversiteye karş1 yabancılaşma yaşamalarına neden olmaktadır. Alan yazında yapılan bazı çalışmalar bu varsayımları destekler mahiyettedir. Nitekim çok sayıda araştırmacı (Atnafu, 2012; Brown vd, 2003; Cadieux, 2002; Hascher ve Hagenauer, 2010; Hernandez-Martinez, 2016; Johnson, 2005;Kumari ve Kumar, 2017) yabancılaşmanın düşük akademik başarı, anti sosyal davranış, isteksizlik, süreçten kopma, istenmeyen davranış, şiddet ve düşük katılım ile sonuçlandığını ileri sürmektedir.

Kavrama ilişkin yapılan araştırma ve değerlendirmeler bağlamında bakıldığında eğitim ve öğretim faaliyetlerinden doğrudan sorumlu olan öğretmen/öğretim elemanları, okul yönetimi ve ailelerin öğrencilere yönelik beklenti, tutum ve yaklaşımlarının yabancılaşma üzerinde dramatik etkilerinin olduğu görülmektedir. Örneğin yabancılaşmaya aracılık eden akademik başarısızlık, katı rekabetçi ortam, aile baskısı (Schulz,2006) ve entelektüel yetenekleri aşan akademik başarı beklentisi gibi farklı değişkenler (Kumari ve Kumar, 2017) öğrencilerin yabancılaşma yaşamalarına neden olmaktır.

Üniversiteler bir ülkenin gelecekteki nitelikli insan kaynağını yetiştiren en üst düzey eğitim kurumlarıdır. Üniversitelerin en önemli girdi ve çıktıları olarak kabul edilen öğrencilerin zihinsel, duygusal ve davranışsal açıdan uyumlu ve sağlıklı olmalarının etkili bir öğrenme ortamıyla yakından ilişkili olduğu değerlendirilmektedir. Öğretim elemanı kaynaklı istenmeyen davranışların öğrenci yabancılaşması üzerinde etkili olup olmadığının belirlenmesi; varsa ise bu etkinin şiddetinin ve yönünün ortaya konması araştırmamızın temel amacını oluşturmaktadır. Ayrıca mevcut çalışmanın istenmeyen davranışların öncüllerinin belirlenmesinde önemli rol oynayacağ 1 ve bunun da öğrenci yabancılaşmasını ortadan kaldıracağ veya en az düzeye indireceği ümit edilmektedir.

Öğrenmeyi engelleyen öğretim elemanı istenmeyen davranışların öğrenci perspektifiyle değerlendirilmesi soruna yönelik çözüm seçeneklerinin sunulmasında ve sorunun çözülmesinde önemli katkılar sunması beklenmektedir. Öğrenci kaynaklı istenmeyen davranışların öğretim elemanlarının alacağı bir takım etkili önlemler sayesinde minimize edilmesi ve dolayısıyla bu davranışların yol açtığı olumsuz sonuçların engellenmesi muhtemeldir. Ancak, öğretmen/öğretim elemanı kaynaklı istenmeyen davranışların kimler tarafindan ve nasıl ortadan kaldırılacağ 1 sorusu eğitim kurumları açısından çözüm bekleyen ciddi bir sorun olarak ortada durmaktadır. Mevcut çalışma bu açıdan önem arz etmektedir. Alan yazında araştırmamızın değişkenleri olan istenmeyen davranışlar ile yabancılaşma arasındaki ilişkiyi inceleyen başka bir çalışmaya rastlanılmaması araştırmamızı önemli kılan bir diğer olgudur. 


\section{Araştırmanın amacı}

$\mathrm{Bu}$ çalışmanın amacı öğretim elemanlarının sergilediği istenmeyen davranışlar ile öğrencilerin yaşadıkları yabancılaşma düzeyleri arasındaki iliş̧iyi incelemektir. Bu amaç doğrultusunda; aşağıdaki sorulara yanıt aranmıştır.

1. Üniversite öğrencilerinin algılarına göre öğretim elemanları kaynaklı istenmeyen davranışların düzeyi nedir?

2. Üniversite öğrencilerinin öğretim elemanları tarafından sergilenen istenmeyen davranışlara ilişkin algıları fakülte, cinsiyet ve sınıfa göre anlamlı düzeyde bir farklılık göstermekte midir?

3. Üniversite öğrencilerinin yabancılaşma düzeyi nedir?

4. Üniversite öğrencilerinin yabancılaşma düzeyleri fakülte, cinsiyet ve sinıfa göre farklılaşmakta mıdır?

5. Üniversite öğrencilerinin öğretim elemanları tarafından sergilenen istenmeyen davranışlarına ilişkin algıları ile öğrencilerin yabancılaşma düzeyleri arasında anlamlı düzeyde bir ilişki var mıdır?

6. Üniversite öğrencilerinin öğretim elemanları tarafından sergilenen istenmeyen davranışlarına ilişkin algıları yabancılaşma düzeylerini yordamakta mıdır?

\section{Yöntem}

$\mathrm{Bu}$ çalışma betimsel araştırma yöntemlerinden ilişkisel tarama modeli olarak tasarlanmıştır. Karasar'a (2005) göre İlişkisel tarama modeli, iki veya daha fazla değişken arasında ilişkileri belirlemek ve muhtemel sonuçları tahmin etmek için kullanılır.

\section{Çalışma Grubu}

Araştırmanın çalışma grubunu, 2017-2018 eğitim-öğretim yılı bahar döneminde Siirt üniversitenin farklı fakültelerinde öğrenimlerine devam etmekte olan 3. ve 4. sınıf öğrencileri oluşturmuştur. Veri toplama araçlarından eksik ya da hatalı olarak doldurulanlar değerlendirilmeye alınmamıştır. Dolayısıyla çalışma grubu 347 (224 kadın, 123 erkek) öğrenciden oluşmaktadır.

Tablo 1. Araştırmaya Katılan Öğrencilerin Demografik Dağılımı

\begin{tabular}{llll}
\hline Demografik değişkenler & Kategoriler & F & $\%$ \\
\hline Cinsiyet & Kadın & 224 & $\% 64,6$ \\
& Erkek & 123 & $\% 35,4$ \\
Fakülte & & \\
& Eğitim & 129 & $\% 37,2$ \\
& Fen-Edebiyat & 135 & $\% 38,9$ \\
& İlahiyat & 83 & $\% 23,9$ \\
& 3. sinıf & 219 & $\% 63,1$ \\
Toplam & 4. sınıf & 128 & $\% 36,9$ \\
\hline
\end{tabular}

Araştırmaya katılan öğrencilerin demografik özellikleri incelendiğinde, kadın öğrenci sayısının erkek öğrenci sayısına göre daha fazla olduğu görülmektedir. Öğrencilerin öğrenim görüldükleri fakültelere göre dağılımları incelendiğinde Fen Edebiyat Fakültesi öğrencilerinin en yüksek frekansa ( $f=135)$ sahip oldukları anlaşılmaktadır. Araştırmaya katılan öğrenciler sınıf 
değişkenine göre değerlendirildiğinde 3. Sınıf öğrencilerinin sayıca daha fazla oldukları gözlenmiştir. Tablodaki veriler dikkate alındığında değerlendirilen öğretim üyesi sayısının öğretim görevlisi sayısından oldukça yüksek olduğu görülmektedir.

\section{Çalışmada Kullanılan Ölçme Araçları}

$\mathrm{Bu}$ çalışmada Öğretim Elemanları İstenmeyen Davranışlar Ölçeği, Öğrenci Yabancılaşma Ölçeği ve Demografik Özellikler formu kullanılmıştır.

\section{Öğretim Elemanları istenmeyen Davranışlar Ölçeği}

Üniversite öğrencilerinin algıladıkları öğretim elemanı kaynaklı istenmeyen davranışlarını ölçmek amacıyla Bozanoğlu (2014) tarafından geliştirilen "Öğretim Elemanları istenmeyen Davranışlar Ölçeği” kullanılmıştır Ölçeğin tümü için Cronbach Alpha değeri ,90 olarak bulunmuştur (Bozanoğlu, 2014). Beş alt boyut ve otuz maddeden oluşan ölçeğin Cronbach's Alpha iç tutarlılık katsayıları, sınıf içi iletiim için ,96, öğretimin yönetimi için, 88, zaman yönetimi için ,88, sınıf dışı iletişim için ,88, derse katılım için ,86 ve ölçeğin tümü için Cronbach Alpha değeri ,97 olarak bulunmuştur. Bu araştırmada ölçeğin Cronbach Alfa değeri ,97 olarak saptamıştır.

\section{Öğrenci Yabancılaşma Ölçeği (ÖYÖ)}

Üniversite öğrencilerinin yabancılaşma düzeylerini belirlemek amacıyla Çağlar (2012) tarafından geliştirilen “Öğrenci Yabancılaşma Ölçeği” kullanılmıştır. Öğrenci yabancılaşma ölçeği dört boyut ve 20 maddeden oluşmaktadır. Ölçeğin tümü için Cronbach Alpha değerini ,86 olarak saptanmıştır. Mevcut araştırmada ölçeğin Cronbach's Alpha iç tutarlılık katsayıları, güçsüzlük boyutu için “.76”,kuralsızlık boyutu için “.71”, soyutlanmışlık boyutu için “.58”, ve anlamsızlık boyutu için “.73” olarak saptanmıştır. Ölçeğin tümü için Cronbach Alfa değeri ,84 olarak bulunmuştur.

\section{İşlem}

İstatistiksel hesaplamalar SPSS 22 paket programı ile yapılmıştır. Öğretim elemanlarının algılanan istenmeyen davranışlanı ve öğrencilerin yabancılaşma düzeylerinin fakülte, cinsiyet ve sınıf değişkenlerine göre farklılaşıp farklılaşmadığı tek yönlü varyans analizi ve bağımsız gruplar $\mathrm{t}$ testi ile incelenmiştir. Tek yönlü varyans analizinde anlamlı fark olması durumunda gruplar arası farklar için TukeyHSD (Tukey HSD post-hoc test 0,05 düzeyinde) sonucuna bakılmıştır. İstenmeyen davranış ile Yabancılaşma arasındaki ilişkiler Pearson korelasyon ve basit lineer regresyon ile analiz edilmiştir.

\section{Normallik Testi}

Verilerin dağılımı için Kolmogorov-Smirnov normallik test istatistiği uygulanmıştır. Yabancılaşma değişkenine ait analizler yapılmış ve verilerin dağılımı simetrik ve normale oldukça yakın olduğu görülmüştür. Bununla birlikte Kolmogorov-Smirnov normallik test istatistiği $\mathrm{KS}=, 026$ ve $\mathrm{p}>0,05$ dir. $\mathrm{Bu}$ sonuca göre verilerin normal dağ 1 lıma uygun olduğu söylenebilir. 


\section{Bulgular}

Araştırmanın bu bölümünde araştırma kapsamında elde edilen bulgulara yer verilmiştir.

Öğretim elemanları istenmeyen davranışlarına yönelik öğrenci algıları analiz sonuçları Tablo 2' sunulmuştur.

Tablo 2. Üniversite Öğrencilerinin Öğretim Elemanları Tarafından Sergilenen İstenmeyen Davranışlara İlişkin Algıları

\begin{tabular}{llcc}
\hline & N & X & SS \\
Boyut & & & 1,280 \\
\hline Sınıf içi iletişim & 347 & 2,26 & 1,124 \\
Zaman yönetimi & 347 & 2,20 & 1,198 \\
Öğrenimin yönetimi & 347 & 2,69 & 1,270 \\
Sınıf dış iletişim & 347 & 2,28 & 1,238 \\
Derse katılım & 347 & 2,23 & 1,072 \\
İstenmeyen Dav. Top. & 347 & 2,33 & \\
\hline
\end{tabular}

Tablo 2'deki ortalamalara göre öğretim elemanlarının istenmenyen davranışları "nadiren" $(\bar{X}=2,33)$ sergiledikleri anlaşılmaktadır. İstenemeyen davranışlar alt boyutlar açısından incelendiğinde, öğretim elemanlarının sınıf içi iletişim, zaman yönetimi, öğrenimin yönetimi, sınıf dışı iletişim ve derse katılım alt boyutlarında istenmeyen davranışları "nadiren" ortaya koydukları görülmektedir. Öğretim elemanlarının en çok öğrenimin yönetimi $(\bar{X}=2,69)$ ve en az zaman yönetimi $(\bar{X}=2,20)$ alt boyutularında istenmeyen davranışlara yöneldikleri sonucuna ulaşılmıştır.

Üniversite öğrencilerinin yabancılaşma düzeylerine ilişkin algılarını belirlemek amacıyla yapılan analiz sonuçlarına ilişkin veriler Tablo 3'te verilmiştir.

Tablo: 3. Üniversite Öğrencilerinin Yabancılaşma Algılarına İlişskin Analiz Sonuçları

\begin{tabular}{lccr}
\hline Boyut & N & X & SS \\
\hline Güçsüzlük & 347 & 2,91 &, 906 \\
Kuralsızlık & 347 & 2,97 &, 949 \\
Soyutlanmışlık & 347 & 2,86 &, 868 \\
Anlamsızlık & 347 & 2,93 & 1,111 \\
\hline Yabancılaşma & 347 & 2,91 &, 906 \\
Toplam & & & \\
\hline
\end{tabular}

Tablo 3'teki dağılım incelendiğinde üniversite öğrencilerinin yabancılaşma algılarının "orta düzeyde katılıyorum" ( $\bar{X}=\mathbf{2 , 9 1})$ aralığında yer aldığı görülmektedir. Diğer bir deyişle üniversite öğrecilerinin arasıra yabancılaşma yaşadıkları görülmektedir. Tablodaki veriler dikkate alındığında, üniversite öğrencilerinin yabancılaşmayı en yüksek düzeyde kuralsızlık $(\bar{X}=2,97)$ alt boyutunda buna karşın en düşük düzeyde ise soyutlanmışlık $(\bar{X}=2,86)$ alt boyutunda yaşadıkları anlaşılmaktadır.

Öğrenci görüşlerine göre öğretim elemanlarının sergiledikleri istenmeyen davranışların cinsiyet ve sınıf değişkenleri açısından incelenmesine ilişkin t-testi sonuçları Tablo 4'te sunulmuştur. 
Tablo 4. Öğretim Elemanlarının İstenmeyen Davranışlarına İlişkin Öğrenci Algılarının Cinsiyet ve Sınıf Değişkenlerine Göre Alınan Puanların T-Testi Sonuçları

\begin{tabular}{llccccc}
\hline Değişkenler & Kategori & $\mathrm{N}$ & $\bar{X}$ & $\mathrm{SS}$ & t-test & $\mathrm{P}$ \\
\hline Cinsiyet & Kadın & 224 & 2,21 & 1,02 & \multirow{2}{*}{$3,042^{* *}$} & \multirow{2}{*}{$003^{* *}$} \\
\multirow{3}{*}{ Sinıf } & Erkek & 123 & 2,57 & 1,11 & & \\
& 3. sinıf & 219 & 2,21 & 1,065 & 2,803 &, $005^{* *}$ \\
\hline
\end{tabular}

$* *: \mathrm{p}<0,01 ; *: \mathrm{p}<0,05$

Kadın ve erkek üniversite öğrencilerinin öğretim elemanları tarafindan sergilenen istenmeyen davranışları algılama düzeyleri birbirinden farklıdır $(\mathrm{t}=3,042 ; \mathrm{p}<0,01)$. Erkek öğrenciler daha fazla istenmeyen davranış algılamaktadırlar. Üniversite öğrencilerinin öğretim elemanları tarafından sergilenen istenmeyen davranışlarına ilişkin algılarının bulundukları sınıf düzeyine göre farklılık göstermektedir $(\mathrm{t}=2,803 ; \mathrm{p}<0,05)$. Bu sonuca göre 4.Sınıftaki öğrenciler 3.Sınıftaki öğrencilere göre istenmeyen davranışları daha yüksek düzeyde algılamaktadır.

Öğrenci görüşlerine göre öğretim elemanlarının sergiledikleri istenmeyen davranışların fakülte değişkeni açısından incelenmesine ilişkin ANOVA sonuçları Tablo 5'te verilmiştir.

Tablo 5. Öğretim Elemanlarının İstenmeyen Davranışı Göstermelerine İlişkin Öğrenci Algılarının Fakülte Değişkenine Göre Karşılaştırılması

\begin{tabular}{|c|c|c|c|c|c|c|c|c|c|}
\hline $\begin{array}{l}\text { Fakülte } \\
\text { (Kategoriler) }\end{array}$ & $\mathrm{N}$ & $\bar{X}$ & $\mathrm{SS}$ & $\begin{array}{l}\text { Varyans } \\
\text { Kaynağ1 }\end{array}$ & $\begin{array}{l}\text { Kareler } \\
\text { Toplamı }\end{array}$ & $\mathrm{sd}$ & $\begin{array}{c}\text { Kareler } \\
\text { Ortalamas1 }\end{array}$ & F-test & $\begin{array}{l}\text { Farkın } \\
\text { kaynağ } 1\end{array}$ \\
\hline Eğitim (e) & 129 & 2,42 & 1,03 & Gruplar arası & 17,67 & 2 & 8,836 & $7,997^{* *}$ & $e-i$ \\
\hline Fen edb. (f) & 135 & 2,50 & 1,19 & Grup İçi & 380,10 & 344 & 1,105 & & $f-i$ \\
\hline İlahiyat.(i) & 83 & 1,94 & 0,80 & Toplam & 397,77 & 346 & & & \\
\hline
\end{tabular}

Tablo 5 incelendiğinde üniversite öğrencilerinin öğretim elemanları tarafindan sergilenen istenmeyen davranışlarına ilişkin algılarının öğrenim gördükleri fakülteye göre farkl1laştı̆̆ görülmektedir $(\mathrm{F}=7,997 ; \mathrm{p}<0,01)$. Yapılan çoklu grup karşılaştırma testine göre bu farkın kaynağı eğitim fakültesi ile ilahiyat fakültesi ve Fen Edebiyat Fakültesi ile İlahiyat Fakültesi arasındaki farktır. Bu sonuca göre ilahiyat fakültesi öğrencilerinin diğer iki fakülte öğrencilerine göre öğretim elemanları tarafından sergilenen istenmeyen davranışları daha düşük düzeyde algıladıkları anlaşılmaktadır.

Yabancılaşma düzeylerine ilişkin öğrenci algılarının cinsiyet, öğretim elemanı ve sınıf değişkenleri açısından incelenmesine ilişkin t-testi sonuçları Tablo 6' da verilmiştir.

Tablo 6. Üniversite Öğrencilerinin Yabancılık Davranışı Göstermelerine İlişsin Algılarının Cinsiyet, Öğretim Elemanı ve Sınıf Değişkenlerine Göre Karşılaştırılması

\begin{tabular}{lllcccc}
\hline Değişkenler & Kategori & $\mathrm{N}$ & $\bar{X}$ & $\mathrm{SS}$ & t-test & $\mathrm{P}$ \\
Cinsiyet & Kadın & 224 & 2,87 &, 719 & 1,836 &, 067 \\
& Erkek & 123 & 3,01 &, 678 & & \multirow{2}{*}{$044^{* *}$} \\
Sinıf & 3. sinıf & 219 & 2,21 &, 755 & 2,027 & \\
& 4. sinıf & 128 & 2,55 &, 615 & & \\
\hline
\end{tabular}

$\overline{* *} \mathrm{p}<0,01$ 
Tablo 6'da görülebileceği üniversite öğrencilerin yabancılaşma algıları cinsiyet ve sınıf değişkenlerine göre farklılaşmamaktadır.

Üniversite öğrencilerinin yabancılaşma düzeylerine ilişkin algılarının faüklte değişkeni açısından incelenmesine ilişkin sonuçlar Tablo 7'de verilmiştir.

Tablo. 7. Üniversite Öğrencilerinin Yabancılaşma Davranışı Göstermelerine İlişkin Algılarının Fakülte Değişkenine Göre Karşılaştırılması

\begin{tabular}{lrrrlrrrr}
\hline $\begin{array}{l}\text { Fakülte } \\
\text { (Kategoriler) }\end{array}$ & $\mathrm{N}$ & $\bar{X}$ & $\mathrm{SS}$ & $\begin{array}{l}\text { Varyans } \\
\text { Kaynağ1 }\end{array}$ & $\begin{array}{l}\text { Kareler } \\
\text { Toplamı }\end{array}$ & sd & $\begin{array}{l}\text { Kareler } \\
\text { Ortalamas1 }\end{array}$ & F-test \\
\hline Eğitim (e) & 129 & 2,97 &, 704 & Gruplar Aras1 & 2,98 & 2 & 1,489 & 3,006 \\
Fen edb. (f) & 135 & 2,96 &, 759 & Grup İçi & 170,36 & 344 &, 495 & \\
İlahiyat.(i) & 83 & 2,75 &, 600 & Toplam & 173,34 & 346 & & \\
\hline
\end{tabular}

Tablo 7'deki veriler dikkate alındığında öğrencilerin yabancılaşma konusundaki düşüncelerinin öğrenim gördüklerin fakülteye göre farklılaşmadığı görülmektedir. Eğitim fakültesi öğrencilerinin diğer fakülte öğrencilerine göre daha yüksek düzeyde yabancılaşma $(\bar{X}=2,97)$ yaşadıkları anlaşılmaktadır.

Üniversite öğrencilerinin öğretim elemanları tarafından sergilenen istenmeyen davranışlarına ilişkin algıları ile öğrencilerin yabancılaşma düzeyleri arasındaki ilişkiyi belirlemek amacıyla Pearson korelasyon katsayıları hesaplanmıştır. Sonuçlar tablo 8'de verilmiştir.

Tablo 8. Öğretim Elemanı İstenmeyen davranışlar ile Üniversite Öğrencilerinin Yabancılaşma Tutumlarına İlişkin Korelasyon Analizi Sonuçları

\begin{tabular}{llll}
\hline İstenmeyen davranış algıları & $\mathrm{N}$ & $\begin{array}{l}\text { Yabancılaşma ile ilişkisi } \\
\text { Korelasyon katsayısı (r) }\end{array}$ & p değeri (sig.) \\
\hline Sınıf içi iletişim & 347 &, $420^{* *}$ &, 000 \\
Zaman yönetimi & 347 &, $351^{* *}$ &, 000 \\
Ögretimin yönetimi & 347 &, $406^{* *}$ &, 000 \\
Sinıf dişı iletişim & 347 &, $412^{* *}$ &, 000 \\
Derse katılım & 347 &, $403^{* *}$ &, 000 \\
İstenmeyen Davr (tüm ölçek) & 347 &, $459^{* *}$ &, 000 \\
\hline
\end{tabular}

$* *: \mathrm{p}<0,01$

Tablo 8'de görüldüğü gibi algılanan istenmeyen davranış ile yabancılaşma arasında pozitif yönlü ve istatistiksel olarak anlamlı bir korelasyon vardır $(r=459 ; p<0,01)$. İstenmeyen davranışın alt boyutları göz önüne alındığında yine alt boyutlar ile yabancılaşma arasında pozitif ve anlamlı ilişkiler olduğu görülmektedir.

Algılanan istenmeyen davranışın yabancılaşmayı yordamasına ait regresyon analizine ilişkin sonuçlar tablo 9'da verilmiştir. İstenmeyen davranışların yabancılaşmayı yordayıp yordamadığını ortaya koymak için yapılan basit regresyon analizi sonucunda istenmeyen davranışlar ile yabancılaşma arasında anlamlı bir ilişki gözlenmiş $\left(R=, 459, R^{2}=, 210\right)$ ve istenmeyen davranışların yabancılaşmanın bir yordayıcısı olduğu görülmüştür $(\mathrm{F}=91,859, \mathrm{p}<0,001)$. İstenmeyen davranışlar, yabancılaşmadaki değişimin \% 21 'ini açılamaktadır. $\mathrm{Bu}$ sonuca göre istenmeyen davranış algısı yabancılaşmayı pozitif ve anlamlı yönde yordamaktadır $(B=, 303 ; p<0,01)$. Regresyon analizi sonucuna göre, yabancılaşmayı 
yordayan regresyon denklemi şu şekildedir: Yabancılaşma $=(0,303 \mathrm{x}$ İstenmeyen Davranış $)+$ 2,213. Bu sonuca göre istenmeyen davranış algısındaki 1 puanlık yükselmenin yabancılaşma algısında 0,303 puanlık bir artışa yol açacağı söylenebilir.

Tablo 9. Öğretim Elemanlarının İstenmeyen Davranışlarının Öğrenci Yabancılaşmasını Yordamasına İlişkin Basit Doğrusal Regresyon Analizi Sonuçları

\begin{tabular}{|c|c|c|c|c|c|c|}
\hline Model 1 & $B$ & B & $T$ & $P$ & $R$ & $R^{2}$ \\
\hline Sabit & 2,213 & & 27,237 & ,000 & & \\
\hline $\begin{array}{l}\text { İstenmeyen } \\
\text { Davranış }\end{array}$ & ,303 & ,459 & 9,584 &, 000 & ,459 & ,210 \\
\hline
\end{tabular}

\section{Tartışma ve Sonuç}

$\mathrm{Bu}$ çalışmada öğretim elemanı kaynaklı istenmeyen davranışlar ile öğrenci yabancılaşması arasındaki ilişki araştırılmıştır. Araştırma bulguları öğretim elemanlarının nadiren istenmeyen davranışlar sergilediklerini ortaya koymaktadır. Sonuçlar alt boyutlar bağlamında incelendiğinde öğretimin yönetimi alt boyutunun en yüksek ortalamaya sahip olduğu görülmektedir. $\mathrm{Bu}$ sonuç alan yazındaki diğer araştırma bulgularıyla paralellik göstermektedir. Örneğin, Özer ve Bozanoğlu (2014) öğretimin yönetimi konusunda istenmeyen davranışların daha yüksek olduğu tespit etmişleridir. Öğretim elemanı kaynaklı istenmeyen davranışların öğretimin yönetimi boyutunda en yüksek ortalamaya sahip olmaları verimlilik ve etkililk açısından düşündürücüdür. Bu bulgu öğretim elemanlarının mesleki yeterlilik ve metodolojide ciddi sorunlar yaşadıklarını ve öğrenme çıktılarının bundan olumsuz etkilediğini göstermektedir. Sonuç olarak istenmeyen davranışlar öğrenmeyi zorlaştırmakta (Kelsey vd, 2004; Sidelinger vd, 2011), katılımı düşürmekte (Broeckelman-Post, Tacconelli, Guzmán, Rios, Calero ve Latif, 2016; Demirtaş, 2016; Bolkan ve Goodboy, 2016; Goodboy ve Bolkan, 2009) ve derse geç gelme, devamsızlık yapma (Vallade ve Malachowski, 2015.) ve derse katılmama (Goodboy ve Bolkan, 2009) gibi olumsıuz davranışlar ile sonuçlanmaktadır.

Öğrencilerin yabancılaşma düzeylerini belirlemek amacıyla yapılan analiz sonuçları öğrencilerin orta düzeyde yabancılaşma yaşadıklarını göstermektedir. Yabancılaşmaya yönelik öğrenci algıları alt boyutlar bağlamında incelendiğinde kuralsızlık boyutunda diğer boyutlara göre daha yükssek düzeyde yabancılaşma yaşandığını göstermekedir. Mevcut sonuçlar konu ile ilgili yapılan diğer çalışma bulgularıyla tutarlılık göstermektedir. Hascher ve Hagenauer'in (2010) araştırma bulgularına göre öğrenciler orta düzeyde yabancılaşma yaşamaktadır. Ortaya çıkan sonucun öğretim elemanlarının istenmeyen davranışlarından kaynaklanması kuvvetle muhtemeldir. Sidelinger'in (2011) araştırma sonuçları bu varsayımımızı doğrular niteliktedir. Nitekim Sidelinger (2011) öğretim elemanlarının istenmeyen davranışlarının öğrencileri öğrenme sürecinden uzaklaştırdığını ileri sürmektedir. Hoy’un (1972) yabancılaşmayı öğrenme sürecinden kopuş olarak nitelendirmesi bu savımızı güçlendiren başka bir saptamadır.

Araştırma sonuçları cinsiyet bağlamında dikkate alındığında erkek öğrencilerin kadın öğrencilere göre istenmeyen davranışları daha yüksek düzeyde algıladıkları görülmektedir. Alan yazında araştırma sonuçlarını destekleyen başka çalışmalar da vardır. Benzer şekilde Özer ve Bozanoğlu (2016) erkek öğrenci ortalamasının kız öğrenci ortalamasına göre daha yüksek olduğunu tespit etmişlerdir. Araştırma bulguları sınıf değişkeni açısından değerlendirildiğinde 4. 
Sınıf öğrencilerinin 3.Sınıf öğrencilerine göre istenmeyen davranışları daha yüksek oranda algıladıkları görülmektedir. Bireylerin bilgi ve deneyimleri arttıkça olayları daha eleştirel bir perspektifle değerlendirmeleri ve mükemmeliyetçi bir kişiliğe bürünmeleri mümkündür. Olaylara eleştirel ve nesnel bir açıdan yaklaşan bireyler en küçük bir detayı bile sorun olarak görmektedirler. 4. Sınıf öğrencilerinin 3. Sınıf öğrencilerine göre daha deneyimli ve bilgi açısından daha donamlı oldukları gerçeği göz önüne alındığında ortaya çıkan sonuç doğal olarak değerlendirilebilir. Analiz sonuçları fakülte değişkeni açısından incelendiğinde Fen-edebiyat fakültesi öğrencilerin en yüksek algıya sahip oldukları ve İlahiyat Fakültesi öğrencilerinin ise en düşük ortalamaya sahip oldukları anlaşılmaktadır. Bu bulgu ile örtüşen başka çalışmalarda mevcuttur (Özer ve Bozanoğlu, 2016). Bu sonucu İlahiyat fakültesinde çalışan öğretim elemanlarının öğrenimleri boyunca aldıkları derslerin din ağırlıklı bir içeriğe sahip olmalarıyla açıklamak mümkündür.

Yabancılaşmaya ilişkin öğrenci algıları cinsiyet değişkenine göre incelendiğinde erkek öğrencilerin daha fazla yabancılaşma yaşadıkları görülmektedir. Yabancılaşma konusunda erkek ve kadın algılarını karşılaştıran araştırma bulgularının birbirleriyle tutarlı oldukları görülmektedir. Nitekim Hascher ve Hagenauer (2010) ve Morinaj ve Hascher (2017) erkek öğrencilerin kı öğrencilere göre daha yüksek düzeyde yabancılaşma yaşadıklarını bulgulamışlardır. Alan yazında mevcut sonuç ile örtüşmeyen çalışmalarda vardır. Örneğin, Atnafu'un (2012) yaptığı araştırmada kız öğrencilerin erkek öğrencilere göre daha yüksek düzeyde yabancılaşma yaşadıklarını tespit etmiştir. Kocayörük ve Şimşek'in (2016) araştırma sonucu ise erkek ve kız öğrencilerin yabancılaşma algılarının farklılaşmadığını göstermektedir. Ortaya çıkan bu farklı sonuçları öğrencilerin yaşadığı toplumun kültürel özellikleriyle ilişkilendirmek mümkündür. Kadın ve erkeğe yönelik toplumsal cinsiyet algıları bu sonucun ortaya çıkmasında etkili olmuş olabilir. Erkeklerin kadınlara göre daha düşük iç motivasyon katsasayılarına sahip olmaları, okula ilgilerinin düşük olması ve öznel iyi oluş düzeylerinin zayıf olması (Hadjar, Krolak-Schwerdt, Priem ve Glock, 2014) gerçekliği gözöüne alındığında mevcut sonuç doğal karşıllanabilir.

Analiz sonuçları sınıf değişkenine göre incelendiğinde 4. Sınıf öğrencilerinin 3. Sınıf öğrencilerine göre yabancılaşmayı daha yoğun yaşadıkları anlaşılmaktadır. Elde edilen bulgular fakülte değişkeni açısından değerlendirildiğinde ilahiyat fakültesi öğrencilerinin diğer fakülte öğrencilerine göre daha düşük düzeyde yabancılaşma yaşadıkları görülmektedir. İlahiyat fakültesinde öğretim elemanı olarak çalışan akademisyenlerin davranışlarını din öğretilerine göre düzenlemesi ve istenmeyen davranışları hak ihlali olarak değerlendirme olası̆ğlı bu sonucun ortaya çıkmasında etkili olması olasıdır.

Araştırma bulguları istenmeyen davranışlar ile yabancılaşma arasında pozitif yönlü orta düzeyde ve istatistiksel olarak anlamlı bir ilişkinin varlığına işaret etmektedir. Araştırmanın iki değişkeni arasındaki ilişki, öğretim elemanlarının sınıf içi ilişki ilişkiden kaynaklanması olasıdır. Çünkü öğretim elemanı ile öğrenci arasındaki ilişkinin negatif yönlü olması öğrencilerin genelde öğretim sürecinden özelde ise öğretim elemanlarında uzaklaşması ile sonuçlanabilir. Nitekim Sidelinger'e (2011) göre öğretim elemanları istenmeyen davranışlar sergilediklerinde öğrenciler öğrenme sürecinden kopmakta ve dersi dinlemeyi bırakıp arkadaşlarıyla iletişime geçmektedir. Benzer şekide Goodboy ve Bolkan (2009) tarafından yürütülen araştırmanın sonuçları istenmeyen davranışların öğrenci katımını engellediğini ortaya 
koymaktadır. Öğretim elemanı-öğrenci arasındaki ilişkinin negatif yönlü olması öğretim elemanının öğrencilere karşı incitici ve tehdit dilini kullanmasından kaynaklı olması muhtemeldir. Vallade ve Myers'in (2014) yaptıkları araştırma bulgularına göre öğrencileri açısından en rahatsız edici istenmeyen davranışlar herkesin gözleri önünde öğrenciye yönelik kullanılan alçaltıcı sözcükler ve tehdit içerikli mesajlardır. İstenmeyen davranışlar bireylerin çevreleriyle iletişim kesmelerine yol açabilir. Claus ve arkadaşlarının (2012) gerçekleştirdikleri araştırmanın sonucu bu iddiayı destekler niteliktedir. Söz çalışmanın bulguları istenmeyen davranışlar algılayan öğrencilerin iletişim kurmada isteksiz davrandıklarını ve anti sosyal davranışlara yöneldiklerini ortaya koymaktadır.

İstenmeyen davranışların yabancılaşmayı yordayıp yordamadığını belirlemek amacıyla yapılan basit regresyon analizi sonucunda öğretim elemanlarının istenmeyen davranışları ile üniversite öğrencilerinin yabancılaşma düzeyleri arasında anlamlı bir ilişki saptanmıştır. İstenmeyen davranışların yabancılaşma davranışındaki değişimin yüzde 21'ini açıkladı̆̆ görülmüştür. Başka bir deyişle istenmeyen davranışların yabancılaşmanın bir yordayıcısı olduğu sonucuna varılmıştır. Bu sonuca göre istenmeyen davranış algısı yabancılaşmayı pozitif ve anlamlı yönde yordamaktadır. Mevcut sonucun öğretim elemanlarının zaman yönetimi, öğretimin yönetimi, derse katılım ve mesleki bilgi ve beceri konularındaki yetersizliklerinden kaynaklanmış olması mümkün olmakla birlikte sonuca etki eden temel faktörün öğretim elemanlarının öğrenciler ile kurmuş oldukları iletişim boyutuyla ilgili olduğu düşünülmektedir. Nitekim Goodboy ve Bolkan (2009) etkili öğrenme sürecinde istenmeyen davranışlarla karşılaştıklarında öğrencilerin iletişimde isteksiz davrandıklarını ve daha az öğrendiklerini ileri sürmektedir. Araştırmanın bu bulgusu Hagenauer'in (2010) öğrenci yabancılaşmasında en etkili faktör öğretmen-öğrenci ilişkisidir savını destekler mahiyettedir. Konu ile ilgili yapılan bir başka çalışmada (Rovai ve Wighting, 2005) sınıf içi etkili iletişim ile öğrenci yabancılaşması arasında negatif bir ilişki saptanmıştır. Hernandez-Martinez' in (2016) araştırma bulguları sınıfta etkili iletişim ağı eksikliğinin öğrencilerde anti-sosyal davranışlara neden olduğunu ortaya koymaktadır. İstenmeyen davranışlar sergileyen öğretim elemanları öğrenciler tarafından genelde yetersiz, saldırgan ve tembel (Kelsey vd, 2004) olarak nitelendirildikleri gerçeği dikkate alındığında istenmeyen davranışların yabancılaşmayı artırması doğal bir sonuç olarak kabul edilebilir. Çünkü öğretmen/öğretim elemanının yetersiz olduğunu düşünen öğrencilerin öğrenme sürecinden kopmaları (Brown vd. 2003; Johnson, 2005) doğal sonuç olarak değerlendirilebilir. Ayrıca yabancılaşmanın eğitim kurumlarında şiddetin artmasına ve sonuç olarak öğrencilerin yaşam kalitelerinin düşmesine arac1lı etmesi beklenir. Nitekim Newmann (1981) yabancılaşmanın öğrencinin yaşam kalitesini olumsuz etkilediğini ve vandalizm, şiddet ve düşük başarı ile sonuçlandığını belirtmektedir.

Öğretim elemanı-öğrenci bağlantısının başka bir deyişle öğretim elemanı-öğrenci ilişkisinin öğrenci başarısında başat bir rol oynadığı gerçeğinden hareketle istenmeyen davranışların önemli boyutlarını oluşturan sınıf içi ve sınıf dışı iletişimin geliştirilmesi gerektiği düşünülmektedir. $\mathrm{Bu}$ sorunu gidermenin etkili yolu öğretim elemanlarının olumlu davranışlar sergilemelerinden (Sidelinger vd, 2011) ve öğrenciler ile daha sağlıklı ilişkiler geliştirmelerinden geçmektedir. Öğretim elemanlarının istenmeyen davranışlar sergilemelerinde, tükenmişlik, deneyimsizlik, yetersiz eğitim (Sidelinger vd, 2011) aşırı iş yükü, yönetimsel sorunlar, öğrenci ilgisizliği ve kabalığı ve kötü çalışma koşulları gibi değişik faktörlerin rol oynaması olasıdır. 
Mevcut araştırma sonuçları okul paydaşlarına ciddi uyarılar olarak değerlendirilmelidir. Çünkü istenmeyen davranışaların eğitim ve öğretim etkinliklerini olumsuz etkileyeceği ve etkili okulların yedi temel ölçütlerinden biri olan güvenli ve düzenli öğrenme çevresini (Lezotte, 1991, Akt. Kirk ve Jones, 2004) yok edeceğini öngörmek kuvvetle muhtemeldir. Nitekim araştırmalar düşük motivasonun akademik başarısızlık ile sonuçlandığını bulgulamaktadır (Ameai vd. 2011; Alkış 2015; Gorham ve Milette, 1997). İstenmeyen davranışların yabancılığa aracılık etmesi sürpriz bir sonuç olarak değerlendirilmemeli ve bu durum bireyin istenmeyen tutum ve davranışlara göstermiş olduğu tepki olarak kabul edilmelidir. Çünkü Meyers ve Rocca'nın (2001) ifadeleriyle birey doğası gereği istenmeyen davranışlar ile karşılaştığında savunma mekanizmaları geliştirir.

Görüldüğü gibi istenmeyen davranışlar öğrenciler arasında yabancılaşma eğiliminin gelişmesi için elverişli bir ortam yaratmakta ve eğitim kurumlarında ayrımcı ve engelleyici bir iklimin oluşmasına aracılık etmektedir. Dillon ve Grout (1976) araştırma bulguları bu savımızı destekler niteliktedir. Söz konusu araştırmada öğretmen kaynaklı istenmeyen davranışların yabancılaşmayı tetiklediği sonucu bulunmuştur. İstenmeyen davranışlar sonucu gelişen yabancılaşma öğrencilerin kendilerini yalnız, pasif ve güçsüz hissetmelerine neden olmaktadır (Dillon ve Grout, 1976).

Gerek mevcut çalışmada elde edilen sonuçlar gerekse alan yazında konu ile ilgili yapılan araştırmalar değerlendirildiğinde istenmeyen davranışlar ve yabancılaşma sorunlarıyla mücadele etmenin eğitim kurumları için yaşamsal bir gereklilik olduğu açıkça görülmektedir. Araştırma sonuçları öğretim elemanı kaynaklı istenmeyen davranışların öğrencileri olumsuz tutum ve davranışlara yönelttiğini ve öğrenme sürecini olumsuz etkilediğini göstermektedir. Öğretim elemanları istenmeyen davranışlar sergilediklerinde öğrencilerin motivasyon düzeyleri düşmekte, derse katılımları azalmakta ve akademik başarıları düşmektedir. Ayrıca istenmeyen davranışların öğrencilerin yaşam kalitesini düşürdüğü, şiddete ve anti sosyal davranışlara yönelttiği bilinmektedir. Dolasıyla istenmeyen davranışların ortadan kaldırılmasında başvurulacak etkili yöntemler aynı zamanda yabancılaşmanın elimine edilmesinde etkili rol oynayabilir.

İstenmeyen davranışlar ve yabancılaşma öğrencileri kendi iç dünyalarına hapsetmekte, yaratıcılıklarını yitirmelerine ve dolayısıyla sosyal çevrelerinden uzaklaşmalarına neden olmaktadır. İstenmeyen davranışların öğrenci ilgisini azalttığı (Broeckelman-Post vd, 2016) olgusundan hareketle bu tür davranışların önüne geçmek için bazı önleyici tedbirlerin alınması eğitim kurumları açısından yaşamsal önem arz etmektedir. Bu amaçla, bir takım yönetimsel çabalar hem istenmeyen davranışları ortadan kaldırabilr hemde yabancılaşmayı azaltabilir. Her sorunun çözümü sorunun kendisindedir gerçeğinden hareketle öncelikle istenmeyen davranışlar ve yabancılaşmaya yol açan faktörler belirlenmelidir. Bu amaçla seminer, hizmet içi eğitimler, anket gibi farklı ölçme araçları ve yüz yüze rehberlik yöntemleri kullanılabilir. Bu önlemlerin yanı sıra yabancılaşmayı ortadan kaldırmak veya en azından azaltmak için dinamik bir süreç yaşayan öğrencilere yönelik sosyal ve kültürel aktiviteler düzenlebilir.

Öğrencileri yabancılaşmanın olumsuz etkilerinden korumada örgütsel ve kurumsal desteğin kritik bir rol oynayacağı düşünülmektedir. Nitekim Chiaburu ve arkadaşları (2014) destekleyici liderlik ve örgütsel destek gibi örgütsel koşulların yabancılaşmaya aracılık neden faktörlerin ortadan kaldırılmasında etkili olduklarını ileri sürmektedir. 
Literatür ile parallelik gösteren çalışmamızın bulguları öğretim elemanı kaynaklı istenmeyen davranışların yabancılaşma üzerindeki etkisini ortaya koyması açısından önem arz etmektedir. Öğrenciyi sosyal, psikolojik ve akademik açıdan olumsuz etkilediği bilinen yabancılaşma olgusuna yol açan faktörlerin belirlenmesi ve ortadan kaldırılması eğitim kurumlarının varlık sebepleri açısından son derece önemli olduğu açıktır. Üniversitelerin bulunduğu coğrafi bölgelerin toplumun sosyo-kültürel ve sosyo-ekonomik düzeyinden etkilendiği gerçeğinden hareketle aynı çalışma farklı bölgelerde ve farklı örneklem gruplarına yönelik yeniden yapılabilir. Elde edilecek sonuçlar mevcut sonuçların genellenebilirliğine katkı sunabilir.

Öğretim Elemanlarının İstenmeyen Davranışlarıyla Öğrenci Yabancılaşması Arasındaki İlişki başlıklı çalışmanın yazım sürecinde bilimsel, etik ve alıntı kurallarına uyulmuş; toplanan veriler üzerinde herhangi bir tahrifat yapılmamış, karşılaşılacak tüm etik ihlallerde "Pamukkale Üniversitesi Eğitim Fakültesi Dergisi Yayın Kurulunun" hiçbir sorumluluğunun olmadığı, tüm sorumluluğun Sorumlu Yazara ait olduğu ve bu çalışmanın herhangi başka bir akademik yayın ortamına değerlendirme için gönderilmemiş olduğunu taahhüt ederim. 


\section{Kaynakça}

Alkış, N. (2015). The influence of personality traits, motivation and persuasion principles on academic performance (Unpublished Doctoral Dissertation). Middle East Technical University, Ankara.

Amrai, K., Motlagh, S. E., Zalani, H. A., \& Parhon, H. (2011). The relationship between academic motivation and academic achievement students. Procedia-Social and Behavioral Sciences, (15) 399402.

Anderman, L., Andrzejewski, C. E., \& Allen, J. (2011). How do teachers support motivation and learning in their classroom? College Teaching Record, 113 (5), 969-1003

Atnafu, M. (2012). Motivation, Social Support, Alienation from the School and their Impact on Students' Achievement in Mathematics: The Case of Tenth Grade Students. Ethiopian Journal of Education and Sciences, 8(1), 53-74.

Ayık. A., Uzun. T., Ataş. U.ve Yücel. E. (2015). Öğrencilerin genel sinizm tutumları ve okula yabancılaşma algıları arasındaki ilişkilerin incelenmesi. International Journal of Social Science. 3 (3). 491-508.

Artar, M., Adiguzel, Z., \& Erdil, O. (2017). Investıgation of the mediator effect of organizatıonal justıce in the relationship between psychological contracting violations and organizational externality on job satısfaction. Research Journal of Business and Management, 4(4), 514-526.

Banai, M., \& Reisel, W. (2003). A test of control, alienation theory among Cuban workers. Management Research, 1, 243-252.

Bolkan, S., \& Goodboy, A. K. (2013). No complain, no gain: Students' organizational, relational, and personal reasons for withholding rhetorical dissent from their college instructors. Communication Education, 62(3), 278-300.

Bozanoğlu, B. (2014). Üniversite öğrencilerinin öğretim elemanları tarafindan sergilenen istenmeyen davranışlara ilişkin görüşleri (Yayımlanmamış yüksek lisans tezi). İn̈̈n̈̈ Üniversitesi, Malatya. ${ }^{13}$

Broeckelman-Post, M. A., Tacconelli, A., Guzmán, J., Rios, M., Calero, B., \& Latif, F. (2016). Teacher misbehavior and its effects on student interest and engagement. Communication Education, 65(2), 204-212.

Brown, M. R., K. Higgins, T. Pierce, E. Hong, and C. Thoma. (2003) Secondary students' perceptions of school life with regard to alienation. Learning Disability Quarterly, 26(4), 227-238.

Cadieux, C. P. (2002). Variables associated with a sense of classroom community and academic persistence in an urban community college online setting. Doctoral dissertation submitted to Old Dominion University, Virginia, ERIC Document Reproduction Service No. Ed474545.

Charlton. T. \& David. K (2013). Managing misbehaviours in schools. Second edition. Routledge. London and New York. [Çevrim-içi: http://www. books.google.com ], Erişim tarihi: 14.12.2018.

Chiaburu. D. S., Thundiyil, T. \& Wang. J. (2014). Alienation and its correlates: A meta-analysis. European Management Journal, 32 (1), 24-36.

Claus, C. J., Booth-Butterfield, M., \& Chory, R. M. (2012). The relationship between instructor misbehaviors and student antisocial behavioral alteration techniques: The roles of instructor attractiveness, humor, and relational closeness. Communication Education, 61(2), 161-183.

Clipa, O., \& Boghean, A. (2015). Stress factors and solutions for the phenomenon of burnout of preschool teachers. Procedia-Social and Behavioral Sciences, 180, 907-915.

Çağlar, Ç. (2012). Öğrenci yabancılaşma ölçeği’nin (öyö) geliştirilmesi. Ĕ̆itim ve Bilim, 37(166), 196205

Dean, D., (1961) 'Alienation, its meaning and measurement, American Sociological Review, 26(5), 753$758 .^{20}$

Demirtaş. H. (2016). The relationship between university students' perceptions of faculty members' undesirable behaviors, their trust for faculty members and class participation. International Online Journal of Educational Sciences, 8 (4), 74-87. 
Dillon, S. V., \& Grout, J. A. (1976). Schools and alienation. The Elementary School Journal, 76(8), 481489. [Çevrim-içi: http:// www.journals.uchicago.edu ], Erişim tarihi: 01.01.2019.

Erdost, B (2018). Yabancılaşma. Derleyen: Barışta Erdost. Ankara: Sol Yayınları. [Çevrim-içi: http://www.solyayinlari.com/solyaz/yab]. Erişim Tarhih: 24.11. 2018.

Erimez. C. ve Giriz. S. (2013). Eğitim fakültesi öğrencilerinin öğretmenlik mesleğine yönelik tutumlarında fakültelerine yabancılaşmalarının rolü Mersin Üniversitesi Eğitim Fakültesi Dergisi, $9(3), 13-26 .^{2}$

Erk1lıç, E. (2012). Örgütsel stresin örgütsel yabancılaşma üzerine etkisi: beş yıldızlı otel işletmelerinde bir araştıma master's thesis, Afyon Kocatepe Üniversitesi, Sosyal Bilimler Enstitüsü.

Fernandez-Balboa, J. M (1991). Beliefs, interactive thoughts, and actions of physical education student teachers regarding pupil misbehaviors. Journal of Teaching in Physical Education, 11(1), 59-78.

Finn, J. D. (1993). School engagement and students at risk. Washington, DC: National Center for Education Statistics; NCES- Reoprt No: 93-470. 1-112.

Frisby, B. N., Berger, E., Burchett, M., Herovic, E., Michael, G., Frisby, B.N., \& Strawser, M.G. (2014). Participation apprehensive students: The influence of face support and instructor - student rapport on classroom participation. Communication Education, 63(2), 105-123.

Goodboy. A., K. \& Bolkan. S. (2009). College teacher misbehaviors: direct and indirect effects on student communication behavior and traditional learning outcomes. Western Journal of Communication, 73(2) 204-219.

Goodboy, A. K., Myers, S. A., \& Bolkan, S. (2010). Student motives for communicating with instructors as a function of perceived instructor misbehaviors. Communication Research Reports, 27(1), 11-19.

Goodwin, B. (2000). Raising the achievement of low performing students. Policy Brief. Document. [Çevrim-içi:http://www.files.eric.ed.gov], Erişim tarihi: 01.11.2018.

Gorham, J., \& Millette, D. M. (1997). A comparative analysis of teacher and student perceptions of sources of motivation and demotivation in college classes. Communication Education, 46 (4), 245 261.

Günay, D. (2002). Sanayi ve sanayi tarihi. Mimar ve Mühendis Dergisi, 31, 8-14.

Hadjar, A., Krolak-Schwerdt, S., Priem, K., \& Glock, S. (2014). Gender and educational achievement, Educational Research, 56(2) 117-125

Hascher. T. \& Hagenauer, G. (2010). Alienation from school. International Journal of Educational Research, 49(6), 220-232.

Hascher, T. \& Hadjar, A. (2018). School alienation-Theoretical approaches and educational research, Educational Research, 60(2), 171-188.

Hernandez-Martinez, P. (2016). "Lost in transition": Alienation and drop out during the transition to mathematically-demanding subjects at university. International Journal of Educational Research, 79, 231-239.

Hoy, W. K. (1972). Dimensions of student alienation and characteristics of public high schools. Interchange, 3(4), 38-52.

Johnson, G. M. (2005). Student alienation, academic achievement, and WebCT use. Journal of Educational Technology \& Society, 8(2), 179-189

Karasar, N. (2005). Bilimsel Araştırma Yöntemi. Ankara: Nobel Yayınevi.

Karl, M (1844) Yabancılaşma (Çev. Kenan Somer, Ahmet Kardam, Sevim Belli Arif Gelen, Yurdakul Fincancı, Alaattin Bilgi), (Derleyen, Barışta Erdost). Sol Yayınları Ankara ${ }^{22}$

Kartal, N. (2017). Sağllk çalışanlarında işe cezbolma, işe yabancılaşma ve performans arasındaki ilişkinin değerlendirilmesi.Yayınlanmamış Yüksek Lisans Tezi, Hacettepe Üniversitesi, Ankara.

Kearney, P., Plax, T. G., Hays, E. R., \& Ivey, M. J. (1991). College teacher misbehaviors: What students don't like about what teachers say and do. Communication Quarterly, 39(4), 309-324.

Kelsey, D. M., Kearney, P., Plax, T. G., Allen, T. H., \& Ritter, K. J. (2004). College students' attributions of teacher misbehaviors. Communication Education, 53(1). 40-45 
Kirk, D. J., \& Jones, T. L. (2004). Effective schools. Assesment Report.Pearson.1-9

Kocayörük, E. \& Şımşek, Ö. F.(2016). Parental attachment and adolescents' perception of school alienation: the mediation role of self-esteem and adjustment. The Journal of psychology, 150 (4) 405-421.

Kumar, P. (2018). Alienation Amoung Male and Female Undergraduate Students of Government And Private Universities. Journal of National Development, 31 (2), 197-202.

Kumari, S. \& Kumar, P. (2017). Educational Quest: An Int. J. of Education and Applied Social Science, 8, Special Issue, 375-380,

Kurz, N., Woolfolk Hoy, A., \& Hoy, W. K. (2007). Predictors of academic optimism: Teachers' instructional beliefs and professional commitment. In annual meeting of the American Educational Research, Chicago, IL. 627-653

Mann, S. J. (2001). Alternative perspective on the student experience: Alienation and engagement. Studies in Higher Education, 26 (1),7-13.

Mau, R. Y. (1992). The validity and devolution of a concept: Student alienation. Adolescence, 27(107), 731-741.

Mazıcı, E. T. (2017). Küreselleşme perspektifinden insan doğası ve halkla ilişkiler faaliyetlerinin dönüşümü üzerine bir inceleme. Akdeniz Üniversitesi Illetişim Fakültesi Dergisi, 27 (27), 97-115.

McPhee, I.\& McEntee. A. (2014). Academic alienation: How academic capitalism impacts on student experience of assessment in higher education in Scotland. The Journal of Higher Education.1-13

Morinaj, J. \& Hascher, T. (2017). School alienation and student well-being: a cross-lagged longitudinal analysis. Theoretical Approaches and Educational Research, 60(2) 171-188.

Morinaj, J., Scharf, J., Grecu, A. L., Hadjar, A., Hascher, T., \& Marcin, K. (2017). School alienation: A construct validation study. Frontline Learning Research, 5(2), 36-59.

Myers, S. A., \& Rocca, K. A. (2001). Perceived instructor argumentativeness and verbal aggressiveness in the college classroom: Effects on student perceptions of climate, apprehension, and state motivation. Western Journal of Communication (Includes Communication Reports), 65(2), 113-137.

Murdock, T. B. (1999). The social context of risk: Status and motivational edictors of alienation in middle school. Journal of Educational Psychology, 91(1), 62- 75.

Myers, S. A. (2002). Perceived aggressive instructor communication and student state motivation, learning, and satisfaction. Communication Reports, 15(2), 113-121.

Newmann, F.M. (1981). Reducing Student Alienation in High Schools: Implications of Theory. Harvard Educational Review, 51(4), 546-564.

Orpen, C. (1978). Discrimination, alienation, and job satisfaction among Coloured and White employees in South Africa. International Journal of Psychology, 13(1), 59-67.

Özatalay. C. (.....) Barlas Tolan'dan hareketle anomi ve yabancllaşma üzerine bir sorgulama. www. academia.edu. adresinden 27.02.2108 tarhinde edinilmiştir.

Özer, N. ve Bozanoğlu, B. (2016). Öğretim elemanları tarafından sergilenen istenmeyen davranışların üniversite öğrencilerinin algılarına göre değerlendirilmesi. Kuram ve Uygulamada Ĕ̆itim Yönetimi, 22(2), 245-266.

Özdemir, A. \& Rahimi, A. (2013). Classroom environment and efl students' feelings of alienation: Reflections on Bahcesehir University Setting, Journal of Education and Practice, 4(6) 48-54

Özler, N. D. E., \& Dirican, M. Ö. (2014). Örgütlerde yabancılaşma ile tükenmişlik sendromu arasındaki ilişkiyi belirlemeye yönelik bir araştırma. Dumlupınar Üniversitesi Sosyal Bilimler Dergisi, 39(39), 291-310.

Polat, M., Dilekmen. M, ve Yasul. F. A. (2015). Öğretmen adaylarında okula yabancılaşma ve akademik öz-yeterlik: bir chaıd analizi incelemesi. Uluslarars1 Eğitim Bilimleri Kongresi. 2(4). 214-232.

Prasad, A., \& Prasad, P. (1993). Reconceptualizing alienation in management inquiry: Critical organizational scholarship and workplace empowerment. Journal of Management Inquiry, 2(2), $169-183$. 
Ratcliff, N. J., Jones, C. R., Costner, R. H., Savage-David, E., \& Hunt, G. H. (2011). The elephant in the classroom: The Impact of Misbehavior on Classroom Climate. Education. 131(2), 306-314.

Rovai, A. P., \& Wighting, M. J. (2005). Feelings of alienation and community among higher education students in a virtual classroom. The Internet and Higher Education, 8(2), 97-110.

Schulz, L.L. (2006). The experience of alienation for males ages 16-19 from high school in the Pacific Northwest: a phenomenological inquiry (Doctoral dissertation).

Seeman, M. (1959). On the meaning of alienation. American Sociological Review, 4(6) 783-791.

Sidelinger, R., J, Bolen, D., Frisby, B.N. \& McMullen, A., L. (2011). When instructors misbehave: An examination of student-to-student connectedness as a mediator in the college classroom. Communication Education, 60(3), 340-361.

Sorcinelli, M.D. (1994). Dealing with troublesome behaviors in the classroom. In K.W. Prichard \& R.M. Sawyer (Eds). Handbook of college teaching: Theory and applications Westport, CT: Greenwood Press. Reprinted with permission of Greenwood Publishing Group, Inc. Westport, CT. 365-373 ${ }^{14}$

Sönmez, V. (1989). Türkiye'de öğretmenin ekonomik durumu. Hacettepe Üniversitesi Eğitim Fakültesi Dergisi, 4(4).77-84

Şimşek. H. ve Akdemir. Ö.A. (2015). Üniversite öğrencilerinde okula yabancılaşma. Curr Res Educ, l(1), 1-12.

Taylor, J. S. (2001). Through a critical lens: Native American alienation from higher education. [Çevrimiçi: https://eric. ed.gov/ED452753], Erişim tarihi: 08. 01.2019.

Tezcan, M. (1998). Toplumsal değişme ve eğitim. Ankara: Ankara Üniversitesi Eğitim Bilimleri Fakültesi Yayınları.

Tolan, B. (1981). Çağdaş toplumun bunalımı, anomi ve yabancılaşma. Ankara, İktisaid ve Ticari İlimler Akademisi Yayınları.

Tummers, G. L., \& Den Dulk, L. (2013). The effects of work alienation on organisational commitment, work effort and work-to-family enrichment. Journal of nursing management, 21(6), 850-859.

Ünsal, S. (2018). Türkiye'de Öğretmenlik Mesleğinin Statüsüne İlişkin Bir Pareto Analizi. Sakarya University Journal of Education, 8(2), 111-130.

Vallade, J. I., \& Myers, S. A. (2014). Student forgiveness in the college classroom: Perceived instructor misbehaviors as relational transgressions. Communication Quarterly, 62(3), 342-356.

Vallade, J. I., \& Malachowski, C. M. (2015). Instructor misbehavior and forgiveness: An examination of student communicative outcomes in the aftermath of instructor misbehavior. Communication Education, 64(3), 301-324.

Warner, B. S., Weist, M. D. ve Krulak, A. (1999). Risk factors for school violence. Urban Education, 34 (1), 52- 68.

Wragg, E. C., \& Dooley, P. A. (1996). Class management during teaching practice, Classroom teaching skills, (Ed.by E. C. Wragg), London: Routledge, 21-46.[Çevrım-İ̧ii:https://books.google.com.tr], erişim tarihi: 16. 01.2019. ${ }^{16}$

Yıldız, K., Akgün, N., \& Yıldız, S. (2013). İşe yabancılaşma ile örgütsel sinizm arasındaki ilişki. The Journal of Academic Social Science Studies, 6(6), 1253-1284.

Yıldız, S., \& Şaylıkay, M. (2014). The effect of organisational cynicism on alienation. Procedia-Social and Behavioral Sciences, 109, 622-627.

Yılmaz, S., \& Sarpkaya, P. (2009). Eğitim örgütlerinde yabancılaşma ve yönetimi, Uluslararası İnsan Bilimleri Dergisi, 6 (2), 314-333.

Yüksel, H. (2014). Yabancılaşma kavramı paralelinde emeğin yabancılaşması ve sonuçları. Abant İzzet Baysal Üniversitesi Sosyal Bilimler Enstitüsü Dergisi, 14(2), 159-188.

Zhang, Q. (2007). Teacher misbehaviors as learning demotivators in college classrooms: A cross-cultural investigation in China, Germany, Japan, and the United States. Communication Education, 56(2), 209-227. 


\section{Extended Abstract}

\section{Introduction}

Today's schools have faced more challenges that inhibit learning process than ever before. The study of variables that influence school effectiveness has emerged for a long time after all the study of instructor misbehaviours has received little interest among scholars in field of inquiry. The concept of misbehaviour hase been identifed by many scholars. The concept of misbeahviours is used to describe any negative behaviours that negatively interferes with instruction and learning (Goodboy \& Bolkan, 2009; Sidelinger et al, 2011). Much of the Schools cannot accomplish their mission unless they build up an orderly learning environment and have compatible and competent instructors. School may enhance learning process through motivated instructors. However, a large number of instructors intoxicate learning environment through their misbehaviours A substantial number of teachers show aggressive, attitudes, and behaviours that inhibit learning process. They create a negative classroom climate (Sidelinger et al. 2011). More specially, many instructors are incompetent, indolent and offensive (Kearney et al, 1991; Kumar \& Mukari 2017) and this inevitably hinders students learning and academic achievement. Because when students witness instructor to be misbehaving, they lose their motivation to learning, break out communication with instructors and peers (Sidelinger et al, 1991). Instructors to be misbehaving can be considered as the main premises of internally and externally motivational failure. In literature instructor misbehaviours are identified as those who inhibit students learning (Sidelinger, 2011, Goodboy \& Bolkan, 2009; Zhang, 2007). In sum instructor misbehaviours have been linked negative outcomes for all stakeholders of schools.

Higher education needs passionate instructor and student to accomplish its goal. In other words, as a higher education institution university needs motivated and eager student to have positive outcomes. However, a large number of undergraduate students are not satisfying the learning process due to various reasons. Alienation can be considered as one of the most significant factor of undergraduate students' dissatisfaction. Alienation is a concept that captured much interest among scholars. The term of alienation is identifying student secession from learning process (Hascher \& Hagenaur, 2010). Numerous reasons can hinder student alienation. Hence, instructor misbehaviours are thought to be the strongest antecedent of student alienation. Instructor misbehaviours lower student interaction with instructor (Hascher and Hagenauer, 2010) results in estrangement in learning process and increase feelings of hostility mong students. Overall, instructor misbeahviours estrange student in learning process (Hoy, 1972).

Mucf of the research has dealt with factors alieanating students from education instituttutions. The term of alienation refers student estrangement in learning (Brown et al, 2003). The studies conducted on alienation proposed that there is a positive relation between alienation and students' behaviours and negative corelation between mishaviours such as failure, drooping out, and absenteeism (Mau, 1992). Newmann (1981) hypotsized that alieanation enchance violence and vandalism among students.

The purpose of this study is to explore how misbehaviours of faculty members effect students' alienation level. Furthermore, the current study aims to investigate to what extend undesirable behaviours of faculty members affect students' alienation level in terms of some demographic factors, such as gender, academic title, faculty and class.

\section{Method}

The main purpose of this paper was to examine the relationship between instructor misbehaviours and students' alienation. More, this study aims to measure mediating role of instructor misbehaviours on undergraduate students' alienation. This study uses quantitative research method. Participants included 247 students (224 males, 123 females) enrolling 
different faculties of a state university in Turkey. The survey data were collected through two questionnaires: The isntrcutor misbehaviour (IMS) Scale and Student Alienation Scale (SAS). The instructor misbehaviours is measured with instructor misbehaviour scale. The instructor misbehaviour scale consists of three five subscales and has 30 items with a Likert-type scale. To measure student alienation SAS which has 20 items with a Likert type scale, was used.

\section{Results}

The present study examined the affects of instructors on students' alienation. Findings of study revealed that instructor performed misbehaviours moderately, meanwhile perception of undergraduate students to alienation was measured as moderate. For the five dimension of instructor misbehaviours results of analysis showed that instruction management received the highest score on other hand lesson participation got the lowest score. For the five dimensions of student alienation, results indicated that normlessness produced the highest score while incompetency produced the lowest score. This findings were similar to results of Özer \& Bozanoğlu (2016) and of Goodboy ve Bolkan (2009).

To examine research to what extent are instructor misbehaviours positively related to students' alienation, a Pearson product moment correlation was conducted to find out if instructor misbehaviours was significantly linked to student alienation. The results revealed that there was significant between instructor misbehaviours and students' alienation. Furthermore, the evidence from this indicate that instructor's misbehaviours have a positive and significant correlation with student alienation. Finally, the most significant contribution of this study is that instructor misbehaviours play a mediating role on student alienation. In other words, when instructor misbehave students feel alienated. The results revelaved instructor misbehaviours function as a mediator for students' alienation.

\section{Discussion}

The results of the study highlighted the importance of misbehaviours regard to learning process. This research focused on mediating role of instructor misbehaviours on students'alienation. The study identified some significant relationships between the instructor misbehaviours and student alienation. More, this study highlighted that the more instructor performs indolent and aggressive behaviours the more students feel isolated and alienated. In this perspective, it might be asserted that all educational leaders must realize importance of instructor behaviours on student achievement and struggle to eliminate negative effects of instructor misbehaviours on student alienation. Positive approaches from school leaders would help instructor to consider their attitudes and behaviours. More importantly, this consciousness would eliminate negative effects of alienation on students. Because it is believed that supportive leadership enable their subordinates will mediate a positive organizational climate, which foster learning process. In addition, instructor and students would strive to elude negative attitudes and behaviours if they feel that that were supported. As we have already mentioned school, achievement is related to healthy and open school climate. When instructors are, regarded as the most critical indicator for school success, are indolent, aggressive and incompetent failure of student is inevitable. Consequently, school leaders must some creative approaches to enhance learning process. They must take preventing precautions to help instructors to be misbehaving. In this term, they can build up a positive interpersonal relationship with instructor. In sum, the results of this study demonstrated that instructor misbehaviours found to be learning demotivators (Zhang, 2007) and they stimulate student alienation. It can be asserted that the results of this study would play a significant role to remove or at least minimize misbehaviours of academic staff and their negative influence on students' alienation. Overall, the results of regression analysis suggest when instructors misbehave students their interest to learning process. The present findings suggestes that instructor misbehaviours can be eliminated through positive approaches, in this context faculty administors should develop creative communication networks for instructors. The results also highlighted the importance of instructor-students interaction. 